\title{
Temel Eğitim Öğretmen Adaylarının Ölçme ve Değerlendirme Araçlarını Seçebilme ve Kullanabilme Yeterlik Algılarının İncelenmesi
} Şule FIRAT DURDUKOCA, Yrd. Doç. Dr., Kafkas Üniversitesi Eğitim Fakültesi, drsulefirat@gmail.com,
ORCID: http://orcid.org/0000-0001-8864-3243

Öz: Bu araştırmanın amacı temel eğitim bölümü öğretmen adaylarının uygulama amacına göre çeşitli ölçme ve değerlendirme araçlarını seçebilme ve kullanabilme yeterlik algılarını belirlemektir. Araştırma betimsel bir çalışma olup tarama modeli kullanılarak yürütülmüştür. Veriler araştırmacı tarafından hazırlanan "Öğretmen Adaylarının Ölçme Değerlendirme Araçlarını Seçebilme ve Kullanabilme Yeterlik Algıları Anketi" kullanılarak toplanmıştır. Araştırmanın nicel verilerinin analizinde frekans (f), yüzde (\%) hesaplamaları ki-kare testi, nitel verilerin analizinde ise betimsel analiz yöntemi kullanılmıştır. Araştırmanın sonucunda, öğretmen adaylarının çeşitli ölçme ve değerlendirme araçlarını seçebilme konusunda yeterlik algılarının yüksek olduğu, ancak seçtikleri bu araçları kullanabilme konusunda aynı düzeyde yeterlik algısına sahip olmadıkları tespit edilmiştir. Adaylar bu duruma yol açan temel faktörün ölçme ve değerlendirme dersi olduğunu belirterek bu dersin teorik ağırlıklı işleniş sürecini eleştirmişlerdir. Ayrıca araştırmada cinsiyet ve anabilim dalı değişkenlerine göre adayların çeşitli ölçme ve değerlendirme araçlarını seçebilme ve kullanabilme yeterlik algıları arasında anlamlı bir farklılık bulunmamıştır.

Anahtar Kelimeler: öğretmen yetiştirme, temel eğitim, ölçme ve değerlendirme, ölçme ve değerlendirme araçları

\section{A Survey on Proficiency Perceptions of Teacher Candidates of Basic Education to Choose and Make Use of Assessment and Evaluation Tools}

\begin{abstract}
The aim of this study is to determine the proficiency perceptions of teacher candidates of basic education to choose and make use of assessment and evaluation tools according to the aim of practice. The study is a descriptive one; it is performed within the scanning model. Data is collected by using "Questionnaire of Proficiency Perceptions of Teacher Candidates to Choose and Make use of Assessment and Evaluation Tools" prepared by the researcher. frequency (f), percentage (\%), chi-square test are used in the analysis of quantitative data of the study; descriptive method is used in the analysis of qualitative data. As a result of the study, it is ascertained that teacher candidates have high-leveled proficiency perceptions to choose various assessment and evaluation tools, yet they don't have enough proficiency to make use of these tools in the same level. Candidates criticize the education process related to assessment and evaluation subject in the theoretical base by focusing on the subject as the main factor for this result. Besides, there is no difference between the proficiency perceptions of candidates to choose and make use of assessment and evaluation tools according to the gender and department variants in the study.
\end{abstract}

Key Words: educating teachers, basic education, assessment and evaluation, assessment and evaluation tools 


\section{GíRiş}

Bilgi çağı olarak adlandırılan 21. yüzyılda dünya ülkelerinin ayakta kalabilmek için yatırım yapacakları alanların başında eğitim gelmektedir. Çünkü bilgi çağında üretilecek nitelikli bilginin temel kaynağı nitelikli eğitim olacaktır. Bu nedenle yapılacak olan her türlü eğitimöğretim faaliyeti, örneğin program geliştirme çalışmaları, öğrencilerin başarı durumlarının değerlendirilerek ilgi ve ihtiyaçlarına göre yönlendirilmesi vb., belirli bir plân dâhilinde yürütülecek, bu faaliyetlerden istenilen başarının sağlanabilmesi için ise düzenli olarak ölçme ve değerlendirme çalışmalarının yapılması gerekecektir.

Eğitim-öğretim sürecinde, öğrenenler tarafından kazanılan istendik davranışların belirlenmesinde, öğrenenlerin öğrenme sürecindeki; hazırbulunuşluklarının, başarı durumlarının, yaşadıkları öğrenme güçlüklerinin tespitinde, motivasyonlarının artmasında, gelişim süreçleri hakkında velilerinin bilgilendirilmesinde, öğretmenlerin ise; öğretme sürecinde kullandıkları öğretim strateji, yöntem ve tekniklerin, öğrenciyi derste aktif kılma durumlarının, öğrencilerle olan iletişimlerinin vb. değerlendirilmesinde, öğrenciler arasındaki bireysel farklılıkların belirlenmesinde ölçme ve değerlendirme çalışmalarından yararlanılmaktadır (Khattak vd., 2015; Tshabalala ve Ncube, 2014; Gay, 2013; Uğurlu ve Akkoç, 2011; Tan, 2009, s.18; Yetkin ve Daşcan, 2006, s.34). Bu doğrultuda ölçme ve değerlendirme çalışmaları, kullanım durumuna göre araç veya amaç olabileceği gibi bu çalışmaların etkili kullanımı, hem öğrencilerin hem de öğretmenlerin gelişimine olanak sağlamaktadır (Munshi, Javed ve Hussain, 2012).

Ülkemizde geçmişten günümüze eğitimde uygulanan ölçme ve değerlendirme sisteminde, dolayısıyla bu sistem içerisinde kullanılan ölçme ve değerlendirme araçlarında, önemli değişiklikler olmuştur. Bu değişikliğin temel nedenlerinden birinin eğitim sistemimizde yaşanan gelişmeler olduğunu söyleyebiliriz. Nitekim 2005 yılında yapılandırmacı anlayışı temele alarak tasarlanan ilköğretim programlarımızda ölçme ve değerlendirme sisteminde yenikliler yapılmıştır.

Yapılandırmacı öğrenme yaklaşımına göre tasarlanan öğretim programlarımızda, öğrenenlerin öğrenme yaşantılarının değerlendirilmesinde "geleneksel ölçme ve değerlendirme araçları" olarak adlandırılan; çoktan seçmeli testler, eşleştirme soruları, doğruyanlış soruları, açık uçlu sorular, sözlü sorular, boşluk doldurma soruları vb. kullanılmaktadır. Ayrıca bu araçlara ek olarak öğretim programlarımızda; performans değerlendirme, öz değerlendirme, akran değerlendirme, proje değerlendirme, portfolyo değerlendirme, gözlem, görüşme, rubric, kavram haritaları vb. "alternatif ölçme ve değerlendirme araçları" olarak adlandırılan araçlar da öğrenme yaşantılarının değerlendirmesinde kullanılmaya başlanmıştır. Böylelikle programlarımız geleneksel ve alternatif ölçme ve değerlendirme araçlarının birlikte kullanımına olanak sağlayan çoklu ölçme ve değerlendirme sistemine uygun olarak tasarlanmıştır (Milli Eğitim Bakanlığı, 2005). Yenilenen öğretim programlarımızda çoklu ölçme ve değerlendirme sisteminin benimsenmesinin temel nedeni, öğrenenlerin, yapılandırmacı yaklaşımın bir gereği olarak, öğrenme süreci ve sonucunda edindikleri bilgi, beceri ve tutumları gösterebilmelerine olanak sağlamak için farklı nitelik ve nicelikteki ölçme ve değerlendirme araçlarına ihtiyaç duyulmasıdır (MEB, 2005a). Yapılandırmacı yaklaşıma göre ölçme ve değerlendirmenin amacı sadece öğrencileri edindikleri bilgi düzeyine yani başarı durumlarına göre sıralamak, öğrenme ürünlerini bir belge ile belgelemek değil, öğrencilerin öğrenmelerine yardımcı olmak, bilginin yanı sıra beceri ve tutumlarını da geliştirerek öğretimi iyileştirmektir (Shepard, 2000). Ancak unutulmaması gereken nokta, çoklu ölçme ve değerlendirme sisteminde kullanılan geleneksel ve alternatif ölçme ve değerlendirme araçlarından birinin diğerine göre en iyi olmaması ve önemli olanın, ihtiyacı karşılayacak nitelikteki araçların, ihtiyaç duyulduğu yer ve zamanda kullanılmış olmasıdır (Yılmaz ve Sünbül, 2007, s.336). Bu sistemde 
temel amaç ölçülecek davranışı en uygun ölçme aracıyla ölçmek ve öğrenme eksikliklerini belirleyerek bu eksikliklerin giderilmesinde öğretmene yol göstermektir (Karamustafaoğlu, Çağlak ve Meşeci, 2012). Dolayısıyla günümüz öğretim programlarının nihai hedeflerlerine ulaşabilmeleri için gerekli olan faktörlerden biri de, öğretmenlerin çeşitli ölçme ve değerlendirme araçlarını tanıma, ölçülecek davranışa uygun olan ölçme ve değerlendirme araçlarını seçebilme ve seçtikleri bu araçları da öğrenme sürecinde aktif olarak kullanabilme konusunda yeterli bilgi ve beceriye sahip olmalarıdır. Ancak literatür incelendiğinde öğretmenlerin bu yeterliklere istenen düzeyde sahip olmadıklarını gösteren pek çok araştırma bulgusuna rastlanmaktadır (Sönmez-Ektem, Erben-Keçici ve Pilten, 2016; Bayat ve Şentürk, 2015; Tshabalala ve Ncube, 2014; Benzer ve Eldem, 2013; Matsenjwa ve Thwala, 2013; Kesten ve Özdemir, 2010; Anıl ve Acar, 2008; Sağlam-Arslan, Devecioğlu-Kaymakçı ve Arslan, 2009; Black ve William, 1998; Ellwein ve Graue, 1996). Bu duruma yol açan temel faktörlerin başında, öğretmen yetiştirme sürecinde öğretmen adaylarına çeşitli ölçme ve değerlendirme araçları konusunda genel olarak yeterli bilgi verilmemesi gelebilir. Nitekim Gelbal ve Kelecioğlu (2007) çalışmalarında, öğretmen yetiştirme programlarında ölçme ve değerlendirmeye yeterince yer verilmemesi nedeniyle son 8-10 yıl içerisinde mezun olan öğretmen adaylarının, öğrenciyi tanıma, ölçme ve değerlendirme amaçlarıyla kullanılan teknikler konusunda önemli eksiklikleri olduğunu ifade etmişlerdir.

Öğretmenlerin hizmet süreçlerine sahip olmaları gereken bilgi ve becerilere yeterince sahip olmadan başlamaları, uygulayacakları öğretim programlarının niteliğinin olumsuz yönde etkilenmesine sebebiyet verebilecek ve başta temel eğitim olmak üzere eğitimin her kademesinde nitelikli eğitim eksikliğine yol açabilecektir. Türk eğitim sisteminde okul öncesi ve ilkokul yıllarını kapsayan temel eğitim, sonraki eğitim kademeleri ve dolayısıyla sonraki öğrenmeler için ön koşul niteliği taşıdığından, eğitimin önemli basamaklarından biridir. Bu kademede görev yapacak olan öğretmenlerin hizmet öncesinde ölçme ve değerlendirme alanına yönelik niteliklerini belirlemek önemlidir. Bu nedenle bu araştırmanın amacı, temel eğitim kademesinde görev yapacak olan öğretmen adaylarının uygulama amacına göre çeşitli ölçme değerlendirme araçlarını seçebilme ve kullanabilme konusunda kendilerini ne derece yeterli bulduklarını belirlemek ve bu yeterlik algılarının adayların cinsiyetlerine ve anabilim dallarına göre farklılaşıp farklılaşmadığını tespit etmektir. Ayrıca araştırma bulgularını daha iyi analiz edebilmek ve yorumlayabilmek adına, adayların çeşitli ölçme ve değerlendirme araçlarını seçebilme ve kullanabilme yeterliklerini etkileyen faktörlere yönelik görüşlerini almak da araştırmanın amacı kapsamındadır. Sarıbaş ve Babadağ’ın (2015) belirttiği gibi eğitimin herhangi bir basamağındaki sorunlar, çözümler ve meydana gelen değişiklikler hem önceki basamakları hem de sonraki basamakları etkilemektedir. Bu bakış açısından hareketle, bu araştırmadan elde edilen sonuçlar ışığında, araştırmaya katılan öğretmen adaylarının genel olarak ölçme ve değerlendirme araçlarını seçebilme ve kullanabilme konusundaki bilgi ve beceri düzeyleri tespit edilmiş olacak ve adayların hizmet öncesinde veya hizmet süreçlerinde (varsa) bu konudaki yetersizliklerini giderebilecek tedbirler alınabilecektir. Araştırmada belirtilen bu amaçlara ulaşmak adına aşağıdaki sorulara yanıtlar aranmaktadır:

1. Öğretmen adaylarının uygulama amacına göre çeşitli ölçme ve değerlendirme araçlarını seçebilme durumuna yönelik yeterlik algıları nasıldır?

2. Öğretmen adaylarının uygulama amacına göre çeşitli ölçme ve değerlendirme araçlarını kullanabilme durumuna yönelik yeterlik algıları nasıldır?

3. Öğretmen adaylarının uygulama amacına göre çeşitli ölçme ve değerlendirme araçlarını seçebilme durumuna yönelik yeterlik algıları adayların cinsiyetlerine ve öğrenim gördükleri anabilim dallarına göre farklılaşmakta mıdır? 
4. Öğretmen adaylarının uygulama amacına göre çeşitli ölçme ve değerlendirme araçlarını kullanabilme durumuna yönelik yeterlik algıları adayların cinsiyetlerine ve öğrenim gördükleri anabilim dallarına göre farklılaşmakta mıdır?

5. Öğretmen adaylarının uygulama amacına göre çeşitli ölçme ve değerlendirme araçlarını seçebilme yeterliklerini etkileyen faktörler nelerdir?

6. Öğretmen adaylarının uygulama amacına göre çeşitli ölçme ve değerlendirme araçlarını kullanabilme yeterliklerini etkileyen faktörler nelerdir?

\section{YÖNTEM}

\subsection{Araştırmanın Modeli}

Araştırma betimsel bir çalışma olup tarama modellerinden ilişkisel tarama modeli kullanılarak yürütülmüştür. Verilen bir durumu olabildiğince tam ve dikkatli bir şekilde tanımlama olarak ifade edilen betimsel araştırmalar, eğitimde yaygın olarak kullanılmaktadır (Büyüköztürk vd., 2010, s.21). Tarama modellerinden ilişkisel tarama modelleri ise iki ya da daha çok sayıdaki değişken arasında birlikte değişim varlığını veya derecesini belirlemeyi amaçlayan araştırma modelleridir (Karasar, 2009, s.81).

\subsection{Araştırmanın Çalışma Grubu}

Araştırmanın çalışma grubunu, 2015-2016 eğitim-öğretim yılı Kafkas Üniversitesi Eğitim Fakültesi Temel Eğitim Bölümü 4. sınıflarında öğrenim gören toplam 108 öğretmen adayı oluşturmaktadır. Çalışma grubunun oluşturulması sürecinde örneklem seçimine gidilmemiş, araştırma tüm evren üzerinden $(n=108)$ yürütülmüştür. Çalışma grubunun oluşturulmasında 4. sınıfların seçilmesinin nedenlerinden biri, öğretmen adaylarının öğretmen yetiştirme lisans öğretim programlarında yer alan ölçme ve değerlendirme dersini almış olmalarıdır. Bir diğer neden ise adayların öğretmenlik uygulaması I ve II dersleri kapsamında temel eğitim kademesinde kullanılan ölçme ve değerlendirme araçları konusunda gözlem yapma imkânını elde etmiş olmaları sayıltısıdır. Çalışma grubunu oluşturan öğretmen adaylarının demografik bilgileri Tablo 1'de sunulmuştur.

Tablo 1

Öğretmen Adaylarının Demografik Özellikleri

\begin{tabular}{cccc}
\hline Anabilim Dalları & Cinsiyet & $\mathbf{N}$ & $\%$ \\
\hline Okulöncesi Eğitimi Anabilim Dalı (OÖE ) & Bayan & 44 & 40 \\
\cline { 2 - 4 } & Erkek & 11 & 10 \\
\hline Sınıf Eğitimi Anabilim Dalı (SE) & Bayan & 20 & 19 \\
\cline { 2 - 4 } & Erkek & 33 & 31 \\
\hline TOPLAM & & 108 & 100 \\
\hline
\end{tabular}

\subsection{Veri Toplama Aracının Geliştirilmesi}

Araştırmanın verileri araştırmacı tarafından hazırlanan "Öğretmen Adaylarının Ölçme ve Değerlendirme Araçlarını Seçebilme ve Kullanabilme Yeterlik Algıları Anketi" kullanılarak toplanmıştır. Anketin oluşturulması sırasında Büyüköztürk (2005) tarafından önerilen; "problemi tanımlama", "madde (soru) yazma", "uzman görüşü alma" ve "ön uygulama yapma" olmak üzere 4 aşamalı anket geliştirme süreci izlenmiştir.

\section{Problemi tanımlama}

Araştırma probleminin tanımlaması sürecine literatürde yer alan öğretim elemanları, öğretmenler ve öğretmen adaylarının çeşitli ölçme ve değerlendirme araçlarını kullanma durumları üzerine yürütülmüş araştırmalar (İzci, Göktaş ve Şad, 2014; Cansız-Aktaş ve Baki, 
2013; Şad ve Göktaş, 2013; Karamustafaoğlu, Çağlak ve Meşeci, 2012; Arslantaş, 2011; Gelbal ve Kelecioğlu, 2007) incelenerek başlanmıştır. Ardından çeşitli ilk, orta ve lise öğretim programlarının ölçme ve değerlendirme yaklaşımları ile MEB Talim ve Terbiye Kurulu Başkanlığı (TTKB) (2005) tarafından yayınlanan "Ölçme ve Değerlendirme Uygulamaları ile ilgili Açıklamalar" konulu genelge incelenmiştir.

\section{Madde yazma}

Hazırlanacak olan anketin madde havuzunu oluşturmak amacıyla 2015-2016 eğitim öğretim yılı Kafkas Üniversitesi Eğitim Fakültesinin 4. sınıflarında öğrenim gören 145 öğretmen adayına "Sizce öğrenme sürecinde ve sonucunda öğrenciye yönelik yapılan çeşitli ölçme ve değerlendirme çalışmalarının amacı nedir?" sorusu sorulmuş ve adayların görüşleri yazılı olarak alınmıştır. Bu görüşler araştırmacı ve iki farklı uzman tarafından içerik analizi kullanılarak analiz edilmiş, sonuç olarak öğretmen adaylarının ölçme ve değerlendirme çalışmalarının amacına yönelik görüşlerinin 5 kategoride toplandığı tespit edilmiştir. Bu kategoriler Tablo 2'de sunulmuştur.

Tablo 2

Öğretmen Adaylarının Ölçme ve Değerlendirme Çalışmalarının Amacına ilişsin Görüşleri

\begin{tabular}{|c|c|}
\hline Kategoriler & Kodlar \\
\hline \multirow{12}{*}{ Tespit etme } & Öğrencilerin; \\
\hline & Öğrenme süreci sonunda öğrenme düzeylerini tespit etme \\
\hline & Neyi, nasıl öğrendiklerini tespit etme \\
\hline & Daha iyi nasıl öğreneceklerini tespit etme \\
\hline & Hazırbulunuşluk düzeylerini tespit etme \\
\hline & $\begin{array}{c}\text { Öğrenme sürecinde kullanacakları strateji, yöntem ve tekniklerin etkililiğini tespit } \\
\text { etme }\end{array}$ \\
\hline & Öğrenme güçlüklerini tespit etme \\
\hline & $\begin{array}{c}\text { Bireysel özelliklerini (ders çalışma alışkanlığı, öğrenme stili, düşünme stili, } \\
\text { öğrenme hızı vb) tespit etme }\end{array}$ \\
\hline & Kavram yanılgılarını tespit etme \\
\hline & Yazılı anlatım becerisini tespit etme \\
\hline & Sözlü anlatım becerisini tespit etme \\
\hline & Bir performans sergileyebilme becerisini tespit etme \\
\hline \multirow[t]{11}{*}{ Beceri geliştirme } & $\begin{array}{l}\text { Üst düzey düşünme becerilerini (yorumlama, yargılama, karar alma, yaratıcı } \\
\text { düşünme, problem çözme vb.) geliştirme }\end{array}$ \\
\hline & Sistemli çalışma becerisini geliştirme \\
\hline & Grupla çalışma becerisini geliştirme \\
\hline & Bağımsız çalışma becerisini geliştirme \\
\hline & Disiplinlerarası ilişki kurma becerisini geliştirme \\
\hline & Dinleme, düşünme, okuma ve yazma becerileri arasında bağlantı kurma \\
\hline & Eski ve yeni bilgileri bütünleştirebilme (örgütleyebilme) becerisini geliştirme \\
\hline & Yeteneklerini sergileme \\
\hline & İlgi alanlarını keşfetme \\
\hline & Öğretmenlerle etkileşimde bulunabilme becerilerini geliştirme \\
\hline & Arkadaşlarla etkileşimde bulunabilme becerilerini geliştirme \\
\hline \multirow[t]{4}{*}{ Değerlendirme } & Başarılarını notla değerlendirebilme \\
\hline & Kendi öğrenme düzeyini değerlendirebilme \\
\hline & Arkadaşları tarafından değerlendirilebilme \\
\hline & Velileri tarafından değerlendirilebilme \\
\hline \multirow[t]{2}{*}{ Derse katılım } & Derse katılım düzeylerini arttırma \\
\hline & Derse yönelik olumlu tutum geliştirmelerini sağlama \\
\hline \multirow[t]{2}{*}{ Öğrenme } & Öğrenilecek konuya yönelik öğrenme motivasyonlarını arttırma \\
\hline & Yeni bilgiler edinebilme \\
\hline
\end{tabular}


Yukarıda sıralanan her bir kategori kapsamındaki kodlar, araştırmanın anket maddelerini oluşturmuştur. Araştırmaya katılan öğretmen adaylarının her bir maddeye yönelik yanıtları "katılıyorum", "karasızım" ve "katılmıyorum" olmak üzere 3'lü derecelendirme yoluyla alınmıştır. Ayrıca adayların bu kapalı uçlu anket sorularına verdikleri yanıtlara yönelik daha iyi çıkarımlarda bulunabilmek, adaylardan araştırmanın problemine ilişkin daha geniş ve ayrıntılı bilgi alabilmek adına ankete iki adet açık uçlu soru eklenmiştir. Böylelikle 30 maddesi kapalı uçlu ve 2 maddesi de açık uçlu olmak üzere toplam 32 maddelik anket formu oluşturulmuştur.

\section{Uzman görüşü alma}

Hazırlanan taslak anket formunun kapsam geçerliğini belirlemek amacıyla daha önce ölçme ve değerlendirme dersini yürüten 2 öğretim elemanının ve temel eğitim kademesinde görev yapan 2'si okul öncesi, 4'ü de sınıf öğretmeni olmak üzere toplam 6 öğretmenin görüşüne başvurulmuştur. Uzmanların anket maddelerine ilişkin görüşleri, her bir maddenin "uygun/geçerli" ve "uygun/geçerli değil" şeklinde değerlendirilebilineceği 2 adet kapalı uçlu sorudan oluşan "uzman değerlendirme formu" hazırlanarak toplanmıştır. Uzmanların her bir maddenin uygunluğu üzerindeki uyuşma düzeyleri \%93 ile \%97 arasında değişmektedir. Büyüköztürk'e (2005) göre anket maddelerinin kapsam geçerliğinden söz edebilmek için, uzmanların her bir maddenin geçerli olduğu üzerindeki uyuşma düzeylerinin \%90 ile \%100 aralığında olmalıdır. Bu durumda araştırmada kullanılacak anket maddelerinin geçerli olduğu söylenebilir.

\section{Ön uygulama yapma}

Uzman görüşleri doğrultusunda son şekli verilen taslak anket formunun güvenirliğini belirlemek amacıyla, form 2015-2016 eğitim öğretim yılı bahar döneminde Kafkas Üniversitesi

Eğitim Fakültesi Temel Eğitim Bölümü 3. sınıflarında ( $n_{O O ̈ E}=45 ; n_{S E}=90$ ) öğrenim gören toplam 135 öğrenciye ön uygulama olarak uygulanmıştır. "Anketin son şeklinin uygulama planı hakkında bir temel oluşturması açısından" (Yücedağ, 1993) cevaplayıcılardan anketi yanıtlamaya başlama ve bitirme saatlerini not etmeleri istenmiştir. Ön uygulama sonucunda anketin yaklaşık 25 dakikalık bir sürede yanıtlanabildiği, soruların açık ve anlaşıı olduğu belirlenmiş ve anket son şekline kavuşturulmuştur. Yücedağ’a göre (1993) anketin yanıtlanması 30 dakikadan az bir süre alıyorsa bu iyi hazırlanmış bir anket demektir. Ön çalışma sonucunda veri toplama aracının Cronbach-alpha güvenirlik katsayısı .91 olarak belirlenmiştir.

\subsection{Verilerin Analizi}

Araştırmanın amacı doğrultusunda toplanan nicel veriler; frekans (f), yüzde(\%) hesaplamaları ve ki-kare testi kullanılarak analiz edilmiştir. Serbestlik derecesinin 1 'e eşit ve 1 'den büyük olduğu, beklenen değeri 5'in altında kalan hücre sayısı, çapraz tablodaki toplam hücre sayısının \%20'sini aşmadığı durumlarda Pearson Ki-Kare testi, teorik (beklenen) dağımlarının 5'in altında olduğu $2 \times 2$ cross tablolarda ise Fisher's Exact testi kullanılmıştır (Can, 2014, s.324). Cross tablolarda gözeneklere düşen denek sayıların yetersiz olması durumunda test uygulanamamıştır. Nitel verilerin analizi ise betimsel analiz yöntemi kullanılmıştır. Betimsel analizde elde edilen veriler, araştırma sorularının ortaya koyduğu temalara göre düzenlenebileceği gibi görüşme sürecinde sorulan sorular da dikkate alınarak düzenlenebilir. Görüşülen bireylerin görüşlerini çarpıcı bir biçimde yansıtmak amacıyla da doğrudan alıntılara sık sık yer verilir (Yıldırım ve Şimşek, 2013, s.256). Bu araştırmada da ankette yer alan açık uçlu sorulara verilen yanıtlardan toplanan verilerle tematik bir çerçeve oluşturulmuş, bu temalara görüşleriyle vurgu yapan öğretmen adaylarının sayıları belirtilmiştir. Betimsel analizin geçerliğini sağlamak amacıyla adayların görüşlerinden doğrudan alıntılara yer verilmiş, analizin güvenirliğini belirlemek için ise adayların açık uçlu sorulara verdikleri yanıtlar araştırmacı dışında bir uzman tarafından daha kodlanmış ve gerekli düzenleme çalışmaları yapılmıştır. 


\section{BULGULAR}

\section{Araştırmanın nicel verilerinden elde edilen bulgular}

Araştırmanın ilk iki alt problemi olan "Öğretmen adaylarının uygulama amacına göre çeşitli ölçme ve değerlendirme araçlarını seçebilme ve kullanabilme yeterlik algıları nasıldır?" problemlerine yönelik toplanan verilerin analizinden elde edilen sonuçlar Tablo 3'de sunulmuştur.

Tablo 3

Adayların Çeşitli Ölçme ve Değerlendirme Araçlarını Seçebilme ve Kullanabilme Yeterlik Algıları

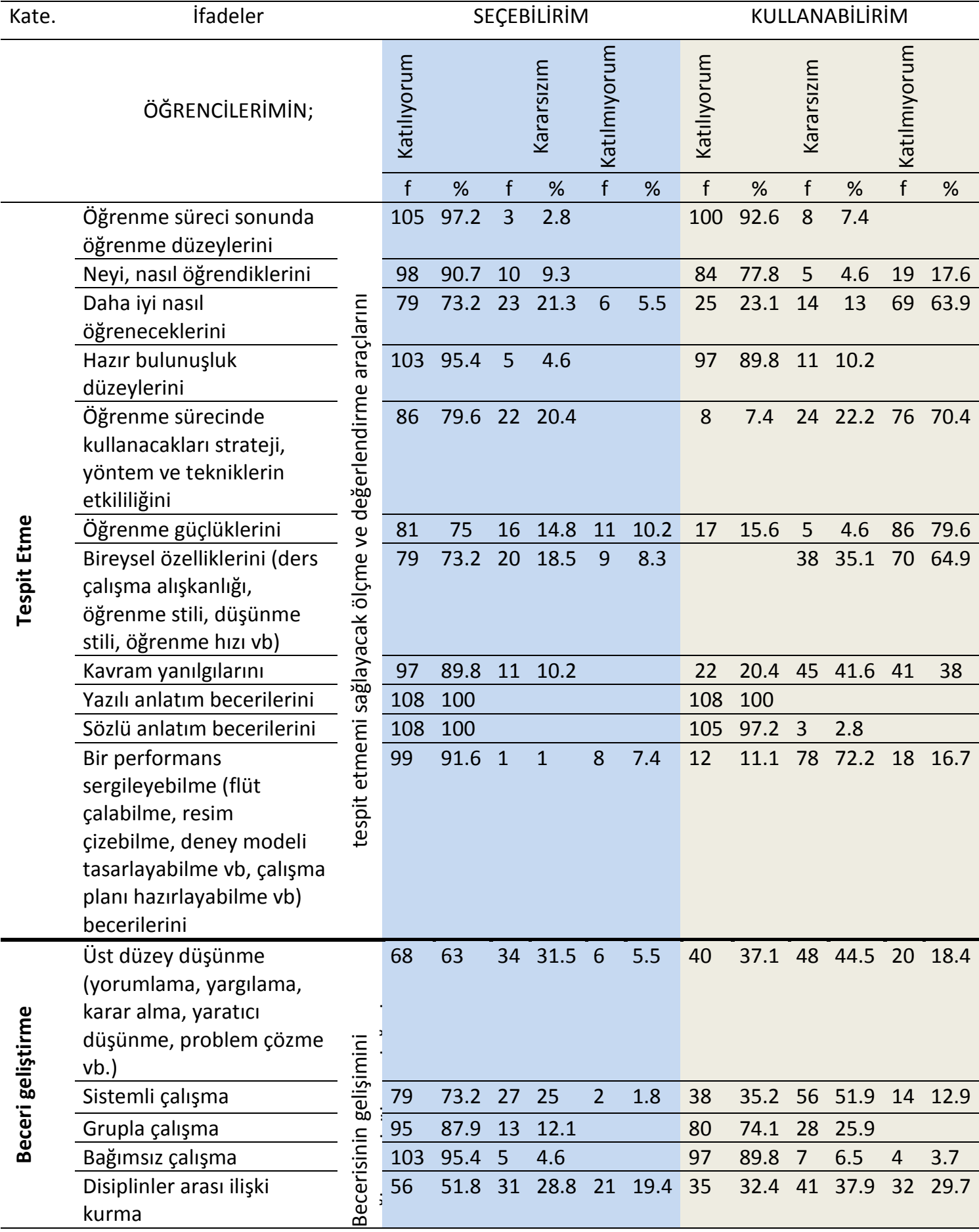




\begin{tabular}{|c|c|c|c|c|c|c|c|c|c|c|c|c|c|c|}
\hline & $\begin{array}{l}\text { Dinleme, düşünme, } \\
\text { okuma ve yazma } \\
\text { becerileri arasında } \\
\text { bağlantı kurma }\end{array}$ & & 59 & 54.7 & 24 & 22.2 & 25 & 23.1 & 27 & 25 & 12 & 11.2 & 49 & 45.4 \\
\hline & $\begin{array}{l}\text { Eski ve yeni bilgileri } \\
\text { bütünleştirebilme } \\
\text { (örgütleyebilme) }\end{array}$ & & 59 & 54.7 & 36 & 33.2 & 13 & 12.1 & 38 & 35.2 & 61 & 56.5 & 9 & 8.3 \\
\hline & Yeteneklerini sergileme & & 52 & 48.1 & 30 & 27.8 & 26 & 24.1 & 37 & 34.2 & 39 & 36.1 & 32 & 29.7 \\
\hline & i̇lgi alanlarını keşfetme & & 40 & 37.1 & 54 & 50 & 14 & 12.9 & 37 & 34.2 & 25 & 23.2 & 46 & 42.6 \\
\hline & $\begin{array}{l}\text { Öğretmenlerle } \\
\text { etkileşimde bulunabilme }\end{array}$ & & 108 & 100 & & & & & 108 & 100 & & & & \\
\hline & $\begin{array}{l}\text { Arkadaşlarla etkileşimde } \\
\text { bulunabilme }\end{array}$ & & 108 & 100 & & & & & 108 & 100 & & & & \\
\hline & $\begin{array}{l}\text { Başarılarını notla } \\
\text { değerlendirebilmeme }\end{array}$ & $\bar{\Xi}$ & 108 & 100 & & & & & 108 & 100 & & & & \\
\hline 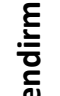 & $\begin{array}{l}\text { Kendi öğrenme düzeyini } \\
\text { değerlendirebilmelerine }\end{array}$ & $\frac{\bar{\pi}}{\frac{\pi}{\pi}}$ & 106 & 98.1 & 2 & 1.9 & & & 104 & 96.2 & 2 & 1.9 & 2 & 1.9 \\
\hline 选 & $\begin{array}{l}\text { Arkadaşları tarafından } \\
\text { değerlendirilebilmelerine }\end{array}$ & 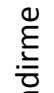 & 106 & 98.1 & 2 & 1.9 & & & 54 & 50 & 54 & 50 & & \\
\hline$\overline{0}$ & $\begin{array}{l}\text { Velileri tarafından } \\
\text { değerlendirilebilmelerine }\end{array}$ & $\frac{\frac{c}{\omega}}{\frac{\omega}{\grave{d}}}$ & 108 & 100 & & & & & 35 & 32.4 & 19 & 17.6 & 54 & 50 \\
\hline$\underline{\underline{E}}$ & $\begin{array}{l}\text { Derse katılım düzeylerini } \\
\text { arttırmaya }\end{array}$ & $\frac{0}{0}$ & 96 & 88.8 & 12 & 11.2 & & & 88 & 81.5 & 10 & 9.3 & 10 & 9.3 \\
\hline 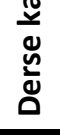 & $\begin{array}{l}\text { Derse yönelik olumlu } \\
\text { tutum geliştirmelerini } \\
\text { sağlamaya }\end{array}$ & $\begin{array}{l}\text { है } \\
\frac{0}{0} \\
\frac{1}{0} \\
0\end{array}$ & 101 & 93.5 & 7 & 6.5 & & & 33 & 30.5 & 48 & 44.5 & 27 & 25 \\
\hline 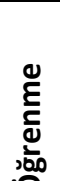 & $\begin{array}{lr}\text { Öğrenilecek } & \text { konuya } \\
\text { yönelik } & \text { öğrenme } \\
\text { motivasyonlarını } & \\
\text { arttırmaya } & \\
\end{array}$ & 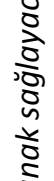 & 93 & 86.1 & 15 & 13.9 & & & 36 & 33.3 & 44 & 40.8 & 28 & 25.9 \\
\hline 0 & $\begin{array}{ll}\text { Yeni } & \text { bilgiler } \\
\text { edinebilmelerine } & \\
\end{array}$ & $\frac{\bar{o}}{0}$ & 101 & 93.5 & 7 & 6.5 & & & 94 & 87 & 7 & 6.5 & 7 & 6.5 \\
\hline
\end{tabular}

Tablo 3'e göre araştırmaya katılan öğretmen adaylarının \%100'ü $(\mathrm{f}=108)$ öğrencilerinin yazılı anlatım becerilerini tespit etmelerine olanak sağlayacak ölçme ve değerlendirme araçlarını "seçebilme" ve "kullanabilme" boyutunda "katılıyorum" düzeyinde görüş belirtmişlerdir. Ayrıca adayların öğrencilerinin; sözlü anlatım becerilerini tespit edecek araçları "seçebilme" boyutunda \%100'ü ( $f=108$ ), "kullanabilme" boyutunda yaklaşı \%97'si ( $f=105)$; öğrenme süreci sonunda öğrenme düzeylerini tespit edecek araçları "seçebilme" boyutunda yaklaşık \%97'si ( $f=105)$, "kullanabilme" boyutunda yaklaşı \%93'ü ( $f=100)$, neyi nasıl öğrendiklerini tespit edecek araçları "seçebilme" boyutunda yaklaşık \%91'i (f=98), "kullanabilme" boyutunda yaklaşık \%78' $\mathrm{i}(\mathrm{f}=84)$, hazırbulunuşluk düzeylerini tespit edecek araçları "seçebilme" boyutunda yaklaşık \%95'i ( $f=103)$, "kullanabilme" boyutunda ise yaklaşık \%90'ı ( $f=97$ ) "katılıyorum" düzeyinde görüş belirttikleri görülmektedir.

Tablo 3'de dikkat çeken diğer bir bulgu ise, öğretmen adaylarının yaklaşık \%90'ının ( $\mathrm{f}=97)$ öğrencilerinin kavram yanılgılarını tespit etmelerini sağlayacak ölçme ve değerlendirme araçlarını "seçebilme" boyutunda "katılıyorum", \%42'sinin ( $f=45)$ ise bu araçları "kullanabilme" boyutunda "kararsızım" düzeyinde görüş belirtmeleridir. Benzer şekilde adayların yaklaşık $\% 92$ 'si ( $\mathrm{f}=99$ ) öğrencilerinin bir performans sergileyebilme becerilerini tespit edecek ölçme ve değerlendirme araçlarını "seçebilirim" boyutunda "katılıyorum" düzeyinde olumlu görüş, 
yaklaşık \%72'si ( $\mathrm{f}=78$ ) ise bu araçları "kullanabilirim" boyutunda "kararsızım" düzeyinde çekimser görüş belirtmişlerdir. Tabloya göre öğretmen adaylarının öğrencilerinin; daha iyi nasıl öğreneceklerini, öğrenme sürecinde kullanacakları strateji, yöntem ve tekniklerin etkililiğini, öğrenme güçlüklerini ve bireysel özelliklerini tespit etmelerine olanak sağlayacak ölçme ve değerlendirme araçlarını seçebileceklerine yönelik yeterlik algılarının olumlu ancak bu araçları kullanabileceklerine yönelik algılarının ise olumsuz olduğu tespit edilmiştir. Sonuç olarak adayların tespit etme kategorisinde yer alan amaçlar için kullanılacak araçları; seçebilme yeterliklerine yönelik algılarının genel olarak olumlu, ancak seçtikleri bu araçları kullanabilme yeterliklerine yönelik algılarının ise olumlu, kararsız ve olumsuz olmak üzere 3 kategoride toplandığı tespit edilmiştir.

Tablo 3 incelendiğinde "beceri geliştirme" kategorisinde göze çarpan ilk bulgu, araştırmaya katılan öğretmen adaylarının öğrencilerinin öğretmenlerle ve arkadaşlarla etkileşimde bulunabilme becerilerinin gelişimini sağlayacak ölçme ve değerlendirme araçlarının seçebilme ve kullanabilme yeterliklerine yönelik algılarının \%100 düzeyinde olumlu olduğudur. Ayrıca adayların yaklaşık \%95'i $(\mathrm{f}=103)$ öğrencilerinin bağımsız çalışma becerilerini geliştirecek ölçme ve değerlendirme araçlarını "seçebilirim" boyutunda, yaklaşık \%90'ı ise ( $f=97$ ) "kullanabilirim" boyutunda "katılıyorum" düzeyinde; yaklaşı \%88'i $(\mathrm{f}=95)$ öğrencilerinin grupla çalışma becerilerini geliştirecek araçlarını "seçebilirim" boyutunda, yaklaşık \%74'ü ( $f=80)$ ise "kullanabilirim" boyutunda "katılıyorum" düzeyinde görüş belirtmişlerdir. Tabloda dikkat çeken diğer bir bulgu ise araştırmaya katılan öğretmen adaylarının \%50'sinin ( $f=54$ ) "öğrencilerimin ilgi alanlarını keşfetme becerilerinin gelişimini sağlayacak araçları seçebilirim" ifadesine yönelik "kararsızım" şeklinde görüş belirtmeleridir. Araştırmaya katılan öğretmen adayları öğrencilerinin; üst düzey düşünebilme, sistemli çalışma, disiplinlerarası ilişki kurma, eski ve yeni bilgileri bütünleştirebilme, yeteneklerini sergileyebilme becerilerini geliştirmeye dönük ölçme ve değerlendirme araçlarını seçebilme yeterliklerine yönelik olumlu ancak bu araçları kullanabilme yeterliklerine yönelik çekimser görüş beyan etmişlerdir. Ayrıca adayların yaklaşık $\% 55^{\prime} i$ ( $f=59$ ) öğrencilerinin dinleme, düşünme, okuma ve yazma becerileri arasında bağlantı kurma becerilerini geliştirecek ölçme ve değerlendirme araçlarını seçebilme yeterliklerine ilişkin olumlu algıya sahipken yaklaşık $\% 45^{\prime} \mathrm{i}(\mathrm{f}=49)$ bu araçları kullanabilecekleri yönünde olumsuz algıya sahiplerdir. Sonuç olarak öğretmen adaylarının beceri geliştirme kategorisi içerisinde belirtilen amaçlar için; çeşitli ölçme ve değerlendirme araçlarını seçme yeterliklerine yönelik algılarının genel olarak olumlu, ancak bu araçların kullanımına yönelik algılarının olumlu, çekimser ve olumsuz olmak üzere 3 kategoride toplandığı belirlenmiştir.

Tablo 3'e göre araştırmaya katılan öğretmen adaylarının değerlendirme kategorisi içerisinde yer alan öğrencilerinin başarılarını notla değerlendirebilmelerine olanak sağlayacak ölçme ve değerlendirme araçlarını seçebilme ve kullanabilme yeterliklerine yönelik algıları \%100 ( $\mathrm{f}=108$ ) düzeyinde olumludur. Ayrıca adayların öğrencilerinin velileri tarafından değerlendirilebilmelerine olanak sağlayacak ölçme ve değerlendirme araçlarını "seçebilme" konusunda yeterlik algılarının \%100 düzeyinde olumlu ( $f=108)$ ancak bu araçların kullanımı konusundaki yeterlik algılarının \%50 ( $f=54)$ oranında olumsuz olduğu görülmektedir. Öğretmen adaylarının yaklaşık \%98' $\mathrm{i} \quad(\mathrm{f}=106)$ öğrencilerinin kendi öğrenme düzeylerini değerlendirebilmelerine olanak sağlayacak ölçme ve değerlendirme araçlarını "seçebilirim" boyutunda, yaklaşık \%96'sı ( $\mathrm{f}=104$ ) ise "kullanabilirim" boyutunda "katılıyorum" düzeyinde görüş beyan etmişlerdir. Adayların \%98'i $(\mathrm{f}=106)$ öğrencilerinin arkadaşları tarafından değerlendirilebilmelerine olanak sağlayacak ölçme değerlendirme araçlarını "seçebilirim" boyutunda "katılıyorum" düzeyinde," kullanabilirim" boyutunda ise \%50'si ( $f=54$ ) katılıyorum, $\% 50$ 'si ( $f=54$ ) ise "kararsızım" düzeyinde görüş bildirmişlerdir. 
Tablo 3'de araştırmaya katılan öğretmen adaylarının genel olarak derse katılım ve öğrenme kategorisi içerisinde yer alan ifadelere yönelik çeşitli ölçme ve değerlendirme araçlarını seçebilme boyutunda olumlu yeterlik algılarına sahip oldukları ancak bu araçların kullanımı boyutunda yeterlik algılarının, araçların kullanım amacına göre, farkılışsığı görülmektedir. Derse katılım kategorisinde adayların yaklaşı $\% 81^{\prime} i(f=88)$ öğrencilerinin derse katılım düzeylerini arttırmaya olanak sağlayacak ölçme ve değerlendirme araçlarını "kullanabilme" boyutuna yönelik "katılıyorum" düzeyinde, yaklaşık \%44'ü $(f=48)$ ise öğrencilerinin derse yönelik olumlu tutum geliştirmelerini sağlayacak ölçme ve değerlendirme araçlarını "kullanabilme" boyutunda "kararsızım" düzeyinde görüş bildirmişlerdir. Benzer şekilde öğrenme kategorisi içerisinde öğretmen adaylarının yaklaşı $\% 87$ 'si $(\mathrm{f}=94)$ öğrencilerinin yeni bilgiler edinebilmelerine olanak sağlayacak ölçme ve değerlendirme araçlarını kullanabilme boyutunda "katılıyorum" düzeyinde, yaklaşık $\% 41$ ' $\mathrm{i}(\mathrm{f}=44)$ ise ögrrencilerinin öğrenilecek konuya yönelik öğrenme motivasyonlarını arttırmaya imkân tanıyacak ölçme ve değerlendirme araçlarını "kullanabilme" boyutunda "kararsızım" düzeyinde görüş bildirmişlerdir. Tablo 3'den elde edilen sonuca göre; araştırmaya katılan öğretmen adaylarının değerlendirme, derse katılım ve öğrenme kategorilerinde yer alan amaçlara göre çeşitli ölçme değerlendirme araçlarını seçebilme yeterliklerine yönelik olumlu algılara sahip oldukları, ancak bu araçların kullanımına yönelik algılarının araçların kullanım amaçlarına göre olumlu, olumsuz ve kararsız olarak farklılaştı̆̆ı tespit edilmiştir.

Tablo 4'de araştırmanın üçüncü alt problemi olan “Öğretmen adaylarının uygulama amacına göre çeşitli ölçme ve değerlendirme araçlarını seçebilme durumuna yönelik yeterlik algıları adayların cinsiyetlerine ve öğrenim gördükleri anabilim dallarına göre farklılaşmakta mıdır?" sorusuna yönelik toplanan verilerin analizinden elde edilen sonuçlar sunulmuştur.

Adayların Cinsiyete ve Anabilim Dalına Göre Ölçme ve Değerlendirme Araçlarını Seçebilme Yeterlik Algıları Arasındaki Fark

\begin{tabular}{|c|c|c|c|c|c|c|}
\hline & \multicolumn{3}{|c|}{ CINSIYET } & \multicolumn{3}{|c|}{ ANABILIM DALI } \\
\hline Madde no & $\chi^{2}$ & sd & $p$ & $\chi^{2}$ & sd & $p$ \\
\hline 1 & & 1 & .63 & & 1 & .51 \\
\hline 2 & & 1 & .51 & .064 & 1 & .80 \\
\hline 3 & 2.124 & 2 & .34 & 3.592 & 2 & .16 \\
\hline 4 & & 1 & .67 & & 1 & .51 \\
\hline 5 & .254 & 1 & .61 & .009 & 1 & .92 \\
\hline 6 & .874 & 2 & .64 & .165 & 2 & .92 \\
\hline 7 & 1.012 & 2 & .60 & .188 & 2 & .91 \\
\hline 8 & & 1 & .25 & .064 & 1 & .80 \\
\hline 9 & \multirow{2}{*}{\multicolumn{3}{|c|}{ TEST UYGULANMADI }} & \multirow{2}{*}{\multicolumn{3}{|c|}{ TEST UYGULANMADI }} \\
\hline 10 & & & & & & \\
\hline 11 & .976 & 2 & .61 & .973 & 2 & .61 \\
\hline 12 & .599 & 2 & .74 & .006 & 2 & .99 \\
\hline 13 & 1.410 & 2 & .49 & .013 & 2 & .99 \\
\hline 14 & & 1 & .34 & .463 & 1 & .49 \\
\hline 15 & & 1 & .67 & & 1 & .51 \\
\hline 16 & .82 & 2 & .96 & .114 & 2 & .94 \\
\hline 17 & 1.161 & 2 & .56 & .020 & 2 & .99 \\
\hline 18 & .209 & 2 & .90 & .192 & 2 & .90 \\
\hline 19 & .284 & 2 & .86 & .016 & 2 & .99 \\
\hline 20 & .627 & 2 & .73 & .037 & 2 & .98 \\
\hline 21 & & & & & & \\
\hline
\end{tabular}




\begin{tabular}{|c|c|c|c|c|c|}
\hline 22 & \multirow{2}{*}{\multicolumn{2}{|c|}{ TEST UYGULANMADI }} & \multirow{2}{*}{\multicolumn{3}{|c|}{ TEST UYGULANMADI }} \\
\hline 23 & & & & & \\
\hline 24 & 1 & .34 & 1 & .74 & 1 \\
\hline 25 & 1 & .34 & 1 & .74 & 1 \\
\hline 26 & \multicolumn{2}{|c|}{ TEST UYGULANMADI } & \multicolumn{3}{|c|}{ TEST UYGULANMADI } \\
\hline 27 & 1 & .34 & .005 & 1 & .94 \\
\hline 28 & 1 & .42 & & 1 & .62 \\
\hline 29 & 1 & .34 & .005 & 1 & .94 \\
\hline 30 & 1 & .42 & & 1 & .62 \\
\hline
\end{tabular}

$(p>.05)$

Tablo 4 incelendiğinde, araştırmaya katılan öğretmen adaylarının cinsiyet ve öğrenim gördükleri anabilim dallarına göre çeşitli ölçme ve değerlendirme araçlarını seçebilme yeterlik algıları arasında anlamlı bir farklılık bulunmamaktadır (p>.05). Bu durum, araştırmanın yürütüldüğü fakültenin Temel Eğitim Bölümü'nünün Sınıf Eğitimi ve Okul Öncesi Eğitimi Anabilim Dallarında öğrenim gören bayan ve erkek öğretmen adaylarının ölçme ve değerlendirme araçlarını seçebilme durumuna yönelik yeterlik algılarının benzer olduğu şeklinde yorumlanabilir.

Tablo 5'de araştırmanın dördüncü alt problemi olan “Öğretmen adaylarının uygulama amacına göre çeşitli ölçme ve değerlendirme araçlarını kullanabilme durumuna yönelik yeterlik algıları adayların cinsiyetlerine ve öğrenim gördükleri anabilim dallarına göre farklılaşmakta mıdır?" sorusuna yönelik toplanan verilerin analizinden elde edilen sonuçlar sunulmuştur.

Tablo 5

Adayların Cinsiyete ve Anabilim Dalına Göre Ölçme ve Değerlendirme Araçlarını Kullanabilme Yeterlik Algıları Arasındaki Fark

\begin{tabular}{|c|c|c|c|c|c|c|}
\hline & \multicolumn{3}{|c|}{ Cinsiyet } & \multicolumn{3}{|c|}{ Anabilim dalı } \\
\hline Madde no & $\chi^{2}$ & sd & $p$ & $\chi^{2}$ & sd & $p$ \\
\hline 1 & & 1 & .42 & & 1 & .62 \\
\hline 2 & .420 & 2 & .81 & .216 & 2 & .89 \\
\hline 3 & 4.441 & 2 & .10 & .133 & 2 & .93 \\
\hline 4 & & 1 & .51 & .147 & 1 & .70 \\
\hline 5 & 1.615 & 2 & .44 & .016 & 2 & .99 \\
\hline 6 & 1.249 & 2 & .53 & .268 & 2 & .87 \\
\hline 7 & & 1 & .10 & .20 & 1 & .88 \\
\hline 8 & .375 & 2 & .82 & .205 & 2 & .90 \\
\hline 9 & \multicolumn{3}{|c|}{ TEST UYGULANMADI } & \multicolumn{3}{|c|}{ TEST UYGULANMADI } \\
\hline 10 & & 1 & .63 & & 1 & .51 \\
\hline 11 & 2.077 & 2 & .35 & .973 & 2 & .61 \\
\hline 12 & .963 & 2 & .61 & .046 & 2 & .97 \\
\hline 13 & 2.241 & 2 & .32 & .148 & 2 & .92 \\
\hline 14 & .033 & 1 & .85 & .013 & 1 & .90 \\
\hline 15 & .279 & 2 & .87 & .004 & 2 & .99 \\
\hline 16 & .860 & 2 & .65 & .016 & 2 & .99 \\
\hline 17 & 4.441 & 2 & .10 & .133 & 2 & .93 \\
\hline 18 & .078 & 2 & .96 & .222 & 2 & .89 \\
\hline 19 & 2.241 & 2 & .32 & .148 & 2 & .92 \\
\hline 20 & .025 & 2 & .98 & 2.732 & 2 & .25 \\
\hline 21 & \multirow{3}{*}{\multicolumn{3}{|c|}{ TEST UYGULANMADI }} & \multirow{3}{*}{\multicolumn{3}{|c|}{ TEST UYGULANMADI }} \\
\hline 22 & & & & & & \\
\hline 23 & & & & & & \\
\hline 24 & .307 & 2 & .85 & .003 & 2 & .99 \\
\hline 25 & 3.835 & 1 & .06 & .037 & 1 & .84 \\
\hline
\end{tabular}


Temel Eğitim Öğretmen Adaylarının Ölçme ve Değerlendirme Araçlarını Seçebilme ve Kullanabilme Yeterlik Algılarının İncelenmesi

\begin{tabular}{lllllll}
\hline 26 & .614 & 2 & .73 & .044 & 2 & .97 \\
\hline 27 & 4.185 & 2 & .12 & 3.210 & 2 & .20 \\
\hline 28 & 3.015 & 2 & .22 & .364 & 2 & .83 \\
\hline 29 & 2.418 & 2 & .29 & .344 & 2 & .84 \\
\hline 30 & .279 & 2 & .87 & .004 & 2 & .99 \\
\hline
\end{tabular}

$(p>.05)$

Tablo 5’e göre araştırmaya katılan öğretmen adaylarının çeşitli ölçme ve değerlendirme araçlarını kullanabilme yeterlik algıları arasında cinsiyete ve anabilim dallarına göre anlamlı bir farklılık bulunmamaktadır. Elde edilen bu sonuç, araştırmanın yapıldığı fakültenin Temel Eğitim Bölümü’nün Sınıf ve Okul Öncesi Eğitimi Anabilim Dalı’nda öğrenim gören bayan ve erkek öğretmen adaylarının çeşitli ölçme ve değerlendirme araçlarını kullanabilme yeterlik algılarının benzerlik gösterdiği şeklinde yorumlanabilir.

\section{Araştırmanın nitel verilerinden elde edilen bulgular}

Araştırmada öğretmen adaylarına yöneltilen "Uygulama amacına göre çeşitli ölçme değerlendirme araçlarını seçebilme ve kullanabilme yeterliğinizi etkileyen faktörler nelerdir?" açık uçlu sorusuna yönelik toplanan nitel verilerin analizinden elde edilen sonuçlar Tablo 6'da sunulmuştur. Yanıtlar sunulurken, adayların belirttikleri ifadelerdeki temel düşünceyi özetleyen cümleler tırnak içerisinde değiştirilmeden aynen yazılmıştır. Sunulan düşüncelerin hangi anabilim dalında öğrenim gören öğretmen adayına ait olduğunu belirtmek amacıyla, Okulöncesi Eğitimi Anabilim Dalı’nda öğrenim gören bir öğretmen adayı için "OÖE”, Sınıf Eğitimi'nde öğrenim gören aday için ise "SE" kısaltmaları kullanılmıştır.

Tablo 6

Adayların Uygulama Amacına Göre Çeşitli Ölçme Değerlendirme Araçlarını Seçebilme Ve Kullanabilme Yeterliğini Etkileyen Faktörler

\begin{tabular}{|c|c|c|c|c|c|}
\hline \multirow{4}{*}{$\begin{array}{l}\text { Seçebilme } \\
\text { Yeterliğini } \\
\text { Etkileyen } \\
\text { Faktörler }\end{array}$} & Kategori & $n$ & $\%$ & Kodlar & Örnek ifadeler \\
\hline & $\begin{array}{c}\text { Ölçme ve } \\
\text { değerlendirme } \\
\text { dersinin içeriği }\end{array}$ & 87 & 97 & $\begin{array}{l}\text { Ölçme ve değerlendirme } \\
\text { dersinin içeriği, ölçme ve } \\
\text { değerlendirme araçlarının } \\
\text { seçimi konusunda bilgi } \\
\text { düzeyini arttıracak } \\
\text { niteliktedir. }\end{array}$ & $\begin{array}{l}\text { "Ders içerisinde uygun olan } \\
\text { ölçme ve değerlendirme } \\
\text { araçlarını seçebilme } \\
\text { konusunda kendimi oldukça } \\
\text { yeterli görüyorum. Bence bu } \\
\text { yeterliğimi oluşturan faktör } \\
\text { aldığım ölçme dersi...(SE 45) }\end{array}$ \\
\hline & Mesleki gelişim & 3 & 3 & Mesleki gelişimi & "Yeterliyim, ama kendi \\
\hline & & & & $\begin{array}{c}\text { sağlayamak amacıyla } \\
\text { yapılan çeşitli çalışmalar, } \\
\text { ölçme ve değerlendirme } \\
\text { araçlarını seçme yeterliğini } \\
\text { etkilemektedir. }\end{array}$ & $\begin{array}{c}\text { yeterliğimi kendim yarattım } \\
\text { galiba. Mesleki gelişimim } \\
\text { için yani. Çok okudum. Çok } \\
\text { araştırdım...(OÖE 50)" }\end{array}$ \\
\hline \multirow{2}{*}{$\begin{array}{l}\text { Kullanabil- } \\
\quad \text { me } \\
\text { Yeterliğini } \\
\text { Etkileyen } \\
\text { Faktörler }\end{array}$} & $\begin{array}{c}\text { Ölçme ve } \\
\text { değerlendirme } \\
\text { dersinin işleniş } \\
\text { biçimi }\end{array}$ & 55 & 69 & $\begin{array}{l}\text { Ölçme ve değerlendirme } \\
\text { dersi teorik ağırlıklı olarak } \\
\text { işlenmektedir. }\end{array}$ & $\begin{array}{c}\text { "Ders çok teorik geçti. } \\
\text { Genelde biz dinleyiciydik. } \\
\text { Çok az uygulama yaptık...(SE } \\
\text { 9)" }\end{array}$ \\
\hline & $\begin{array}{l}\text { Türkiye'de } \\
\text { uygulanan } \\
\text { eğitim sistemi }\end{array}$ & 25 & 31 & $\begin{array}{l}\text { Ölçme ve değerlendirme } \\
\text { uygulamaları çoğunlukla } \\
\text { geleneksel yaklaşımla } \\
\text { sürdürülmektedir. }\end{array}$ & $\begin{array}{c}\text { “Alternatif araçlar } \\
\text { kullanımında yetersiz } \\
\text { olduğunu düşünüyorum. } \\
\text { Çünkü hep geleneksel } \\
\text { araçlarla } \\
\text { değerlendirildik...(OÖE4O)" }\end{array}$ \\
\hline
\end{tabular}

Tablo 6’ya göre araştırmaya katılan öğretmen adaylarının uygulama amacına göre çeşitli ölçme ve değerlendirme araçlarını seçebilme yeterliklerini etkileyen faktörlere ilişkin 
görüşlerinin; ölçme ve değerlendirme dersinin içeriği ( $f=87, \% 97)$ ve mesleki gelişim ( $f=3, \% 3)$ olmak üzere 2 kategoride toplandığı görülmektedir. Araştırmaya katılan öğretmen adayları, ölçme ve değerlendirme araçlarını seçebilme yeterliklerini etkileyen faktörlerin başında ölçme ve değerlendirme dersinin içeriğinin yer aldığını $(f=87, \% 97)$, aldıkları bu ders sayesinde ölçülecek davranışa uygun ölçme ve değerlendirme araçlarının seçimi konusunda bilgi düzeylerini arttırdıklarını belirtmişlerdir. Adaylardan biri "Ben okulöncesi öğretmeni olacağım. Bizim alanımız için kullanabileceğimiz ölçme araçları diğer branşlara göre daha sınırlı. O yüzden bu araçların hangi amaçlarla kullanabileceğimi iyi bilmem gerekiyor. Ölçme dersi bence bana bu bilgiyi verdi. (OÖE 35)" şeklinde görüşünü belirtmiştir. Adaylardan (SE 45) ise "Ders içerisinde uygun olan ölçme ve değerlendirme araçlarını seçebilme konusunda kendimi oldukça yeterli görüyorum. Bence bu yeterliğimi oluşturan faktör aldığım ölçme dersi. Derste hocamız, güzel bir ölçme kitabını bize önerdi ve o kitaba bağlı kalarak dersi işledi, biz de dinledik. Vize ve final sınavlarını da klasik yaptı. Hangi amaçla hangi araç kullanılır bu konuda kendimi yeterli görüyorum, öğretmen olunca da yapacağım işe göre uygun aracı seçebileceğimi düşünüyorum." diyerek ölçme ve değerlendirme dersinin lisans öğretim programındaki varlığından ve dersin işleniş şeklinden memnuniyetini ifade etmiştir. Bu konuda (SE 21) ise "Yeterliğimi oluşturan faktör üçüncü sınıfta aldığım ölçme dersi. Ölçme dersinde yeterli bilgi birikimim oluştu. Bu ders hangi amaçla hangi ölçme aracı seçilir konusunda bilgi edinmemi sağladı, öğretmenlik uygulaması dersinde de gerçekten bu bilgiyi edinmişmiyim diye kendimi yoklama imkânım oldu. Staj hocamızın emekliliği gelmek üzere, bazı ölçme araçlarını bilmiyor bu yüzden kullanamıyor ben ona bu konuda yardımcı oluyorum. Uygun olan ölçme aracını söylüyorum. Ölçme dersi bence lisanstaki en önemli derslerden biri. (SE 21)"diyerek ölçme ve değerlendirme dersinin öneminden de bahsetmiştir. Aynı doğrultuda (OÖE 12) ise görüşünü "Öncelikle mesela öğrencim renkleri öğrendi mi acaba, öğrenciyi yoklamak için hangi ölçme aracını seçmem gerekir diye kendime sorunca, cevap alabiliyorum, gözlem yapabilirim veya doğru yanlış testlerini soru haline getirip sorabilirim diyebiliyorum. Evet, ölçme araçlarını seçme konusunda yeterliyim. Yeterliğimi oluşturan üçüncü sınıfta aldığım ölçme dersi. Bu derste tek tek hangi ölçme aracı hangi amaçla kullanılır öğrendik. İyi de oldu."diyerek açıklamıştır.

Mesleki gelişim ( $f=3, \% 3)$ kategorisi içerisinde ise adaylar, uygulama amacına göre çeşitli ölçme ve değerlendirme araçlarının seçimi konusunda kendilerini yeterli gördüklerini, bu yeterliğin oluşmasındaki temel faktörün bu araçlarının kullanımı konusunda kendilerini geliştirmek istemeleri, farklı ölçme ve değerlendirme ders kitaplarını ve bu konuda yürütülmüş çeşitli makaleleri incelemeleri olduğunu ifade etmişlerdir. Adaylardan (SE 22) "Staj hocamız bu konuda çok zorluk yaşıyor. Bence bu konu oldukça önemli. Çünkü dersi işliyorsan ölçme ve değerlendirme de yapman gerekir. Ama acaba hangi ölçme aracını kullanman gerekir? Bir ögretmen bunun bilgisine sahip olmalı bence. Öğretmenlik yaşantımda zorluk yaşamak istemiyorum, mesleki gelişimimi sürdürmek istiyorum. Evet ölçme araçlarının seçimi konusunda kendimi yeterli görüyorum ama yine de ölçme ders kitaplarını inceliyorum, hatta geçenlerde bir makale buldum bu konuda, onu okudum. Kastamonu üniversitesinden hocalar yapmışlardı makaleyi. Çok beğendim. Mesleki gelişimim için bunlar şart. Ama şunu da belirtmek isterim ki Ahhh bu KPSS. Çok zamanımı alıyor. Daha çok makale taramak isterim ama KPSS'ye çalışmak zorundayım. Neticede atanırken kaç makale okudun diye kim soruyor ki KPSS ve sözlü sonuçlarına bakılıyor." şeklinde düşüncesini belirtmiştir. Aynı konuda (OÖE 3) ise "Evet, bu konuda kendimi yeterli buluyorum. Ama yeterli olmamı sağlayan bence yine benim, kendimim yani. Çünkü üçüncü sınıfta hocamızın tavsiye ettiği tüm ölçme kitaplarını aldım, galiba dört tane kitabım var. Konuyu ben bu dört kitaptan birden takip ettim, yetmedi makale okudum. Staja gittim kafama takılan şeylerle ilgili makale inceledim. Geçen hafta okulöncesi öğrencilerinin yaratıcıklarını nasıl geliştirebilirim nasıl ölçebilirim diye düşündüm. Hemen araştırma yaptım. Okul öncesinde kullanılabilecek yaratıcılık testleri varmış, onları indirdim bu hafta uygulayacağım. Bir insanın gelişimi yine kendi elindedir. Mesleki gelişimi de kendi 
elindedir bence. Mesleki gelişimim için daha neler yaparım da önce KPSS. " diyerek ölçme ve değerlendirme araçlarını seçebilme yeterliğini etkileyen temel faktörün mesleki gelişimi için sarf ettiği çaba olduğunu açıklamaya çalışmıştır. Adaylardan (OÖE 50) ise "Yeterliyim, ama kendi yeterliğimi kendim yarattım galiba. Mesleki gelişimim için yani. Çok okudum. Çok araştırdım. Şimdi emeklerimin karşılığını alıyorum. Stajda hiç zorlanmıyorum. Staj hocamız da buna benzer sorular soruyor bize. Daha önce bir çocuğun bir olaya farklı bakış açıklarıyla bakabilme düzeyini nasıl yoklarsın diye sormuştu. Ona bir sürü yol, yöntem, ölçme aracı sıralamıştım. Bu kadar bilgim olduğuna inanamamıştı." şeklinde görüşünü açıklamıştır.

Tablo 6 incelendiğinde öğretmen adaylarının uygulama amacına göre çeşitli ölçme değerlendirme araçlarını kullanabilme yeterliklerini etkileyen faktörlerin; ölçme ve değerlendirme dersinin işleniş biçimi $(f=55, \% 69)$ ve Türkiye'de uygulanan eğitim sistemi $(f=25$, \%31) olmak üzere 2 kategoride toplandığı görülmektedir. Ölçme ve değerlendirme dersinin işlenişi kategorisinde, adaylar dersin öğretme-öğrenme süreci içerisinde fazlaca uygulama yapma imkânı elde edemediklerini, dersin teorik ağılıklı olarak işlendiğini ve bu nedenle ölçme ve değerlendirme araçların seçimi konusunda bilgi düzeyinde oldukça yeterli olduklarını ancak bu araçların kullanımı konusunda kendilerini aynı yeterlik düzeyinde görmediklerini ifade etmişlerdir. Adaylardan (SE 43) "Yeterliğimi etkileyen faktör dersin işlenişi oldu. Hocamız ölçme araçlarının nasıl kullanılacağını anlattı ama özellikle alternatif ölçme araçlarını derste nasıl kullanacağımıza yönelik uygulama yapmadı. Portfolyo dedi, performans ödevi dedi, yapılandırılmıs grid dedi ama derste hiçbirinin uygulamasını yapmadık. Şimdi bana performans ödevi nedir ne işe yarar diye sorsanız bilirim ama öğrencilerine alanınla ilgili bir performans ödevi ver veya bu performans ödevi nasıl değerlendirilir diye sorsalar herhalde bocalarım." diyerek ölçme ve değerlendirme dersinin işlenişine yönelik eleştirilerde bulunmuştur. Benzer şekilde (OÖE 1) ise "Hangi aracı nasıl kullanacağım konusunda kendimi yeterli bulmuyorum. Yetersizliğimi bence tek nedeni ölçme dersi. Ders öyle teorik geçti ki her şeyi bilgi düzeyinde çok iyi öğrendim ama uygulama düzeyinde çok sınırlı öğrendim. Keşke mesela bir mikro öğretim çalışması yapsaydık, arkadaşlarımız okulöncesi öğrencileri gibi davransalardı bir konuyu işleyip öğrendiğimiz ölçme ve değerlendirme araçlarını kullanarak değerlendirme yapsaydık. Ama nerdeee!"şeklinde dersin işlenişini eleştirerek, öğrenme sürecinin daha verimli geçmesi adına öneride de bulunmuştur. Adaylardan (SE 9) ise "Ders çok teorik geçti. Genelde biz dinleyiciydik. Çok az uygulama yaptık. Bu durum aslında biz öğretmen adayları için çok sıkıntılı bence. Çünkü teorik olarak çok şey biliyorum ama bildiklerimi nasıl uygulayacağım işte onu bilmiyorum. ikisi arasında bağlantı kuramıyorum. Deste bir sürü ölçme aracı gördük ama biz galiba öğretmen olunca yine geleneksel ölçme araçlarını kullanacağız. Biz de öğretmen olunca kendi yetiştiğimiz ölçme araçlarını kullanacaksak bu kadar farklı ölçme aracı bilmeye ne gerek var ki? Bence ölçme dersinin bazı konuları sadece bilgi yığını, gereksiz." diyerek aslında bizlere dersin işleniş şeklinin, dersin içeriğinin önemine yönelik öğretmen adaylarının görüşlerini nasıl etkileyebileceğini göstermektedir.

Türkiye'de uygulanan eğitim sistemi ( $f=25, \% 31)$ kategorisinde, öğretmen adayları ülkemizdeki mevcut eğitim sisteminin kâğıt üzerinde yapılandırmacı yaklaşım üzerine temellendiğini ancak sistemin bir parçası olan ölçme ve değerlendirme uygulamalarının genel olarak geleneksel yaklaşımla sürdürüldüğünü ifade etmişlerdir. Adaylar bu durumun ülkemizdeki her öğretim kademesi için geçerli olduğunu belirterek lisans öğrenim süreçlerinde de sıklıkla geleneksel ölçme araçları ile değerlendirildiklerini belirtmişlerdir. Böylesi bir uygulamanın da, ölçme ve değerlendirme çalışmalarının sadece öğrenci başarısını belirlemek, öğrenciyi notla değerlendirmek olduğu ve bu amaçla çoğunlukla geleneksel ölçme araçlarının kullanılması gerektiği şeklinde bir algıya yol açtığını ifade etmişler, bu nedenlerle amaca uygun özellikle alternatif ölçme değerlendirme araçlarının kullanımı konusunda kendilerini yetersiz 
bulduklarını ifade etmişlerdir. Bu doğrultuda adaylardan bazılarının görüşleri aşağıda sunulmuştur.

\begin{abstract}
"Öncelikle şunu söylemeliyim ki özellikle alternatif ölçme araçlarının kullanımı konusunda kendimi tamamen yeterli hissetmiyorum. Yetersiz olmamın en büyük sebebi Türkiye'deki eğitim sistemi. Dört yıl boyunca hocalarımı hep Finlandiya eğitim sisteminden bahsettiler. Bizimkinden çok farklı. Ben ilkokuldan beri test çözüyorum, yazılı sınav oluyorum. Hani yapılandırmacılık, hani alternatif değerlendirme? Lisede birkaç hocamız performans ödevi verirdi, nasıl yapacağımızı bilmezdik, internetten çıkarırdık hoca da kızardı yine test yapardı. Ya da işte öyle geçerdik. Eğitim sistemimiz kâğıt üzerinde mükemmel görünüyor keşke Bakanlık yetkilileri bir de sınıflara girseler de görseler. Ilkokuldan üniversiteye kadar durum aynı. Fakültede de testten, yazılı sınavdan başka ne gördük ki! Hoca bizi dersten geçirmek istiyorsa test, istemiyorsa yazılı sınav yapıyor. Yazılı sınav ceza gibi.(SE 31)"
\end{abstract}

"Yetersizliğimin nedeni \%90 Türkiye'deki eğitim sistemi. Yapılandırmacılık geleneksel ve alternatif ölçme araçları birlikte kullanılsın diyor. KPSS'ye çalışırken sürekli bunları okuyoruz, derslerde hocalarımız da söylüyor iyi de neden uygulanmıyor? Uygulanmayacaksa sistem neden öğrenci merkezli olarak hazırlanıyor. Türk eğitim sisteminde sıkıntılar var. (SE 2)"

"Alternatif ölçme araçlarının kullanımı konusunda yetersizim, diğerlerini daha iyi kullanacağıma inanıyorum. Ama ben okulöncesi öğretmenliğinde okuyorum. Ben öğrencilere sıkıkla alternatif ölçme araçlarını kullanacağım. Iyişallah başarıyla kullanabilirim. Çünkü ilkokulda üniversiteye kadar hep test tekniği ile yetiştik. (OÖE 20)"

"Alternatif araçlar kullanımında yetersiz olduğunu düşünüyorum. Çünkü hep geleneksel araçlarla değerlendirildik. Aslına bakarsanız ölçme ve değerlendirme denilince aklıma hep not, başarı-başarısızlık, test, sözlü ve yazılı sınav geliyor. Hiç yapılandırılmış grid, proje veya rubrik gelmiyor ki. Ben okulöncesi öğretmeni olacağım. Öğrenciyi test yapamam, yazılı yapamam, atanınca artık çaresine bakmaya çalışırım. (OÖE 40)"

\title{
4. SONUÇ, TARTIŞMA VE ÖNERILER
}

Öğretmen adaylarının ölçme ve değerlendirme alanına yönelik niteliklerinin sorgulandığı bu araştırmadan çıkan genel sonuç; araştırmaya katılan temel eğitim bölümü öğretmen adaylarııın uygulama amacına göre çeşitli ölçme ve değerlendirme araçlarını seçebilme konusunda kendilerini oldukça yeterli buldukları ancak seçtikleri bu araçları kullanabilme konusunda kendilerini aynı düzeyde yeterli bulmadıklarıdır. Bu araştırmaya katılan öğretmen adaylarının öğrencilerin; "daha iyi nasıl öğreneceklerini, öğrenme sürecinde kullanacakları strateji, yöntem ve tekniklerin etkililiğini, öğrenme güçlüklerini, bireysel özelliklerini tespit etmek", "dinleme, düşünme, okuma ve yazma becerileri arasında bağlantı kurma becerilerini geliştirmek, ilgi alanlarını keşfetmek" ve "velileri tarafından değerlendirilebilmelerine imkân tanımak" amacıyla çeşitli ölçme ve değerlendirme araçlarını seçebildikleri yani bu amaçlar için hangi ölçme ve değerlendirme araçlarının kullanılabilineceğinin teorik bilgisine sahip oldukları tespit edilmiştir. Ancak adayların özellikle bu amaçların ölçülmesi ve değerlendirilmesi için seçtikleri araçlarının kullanımı konusunda yeterli bilgi ve beceriye sahip olmadıkları belirlenmiştir. Ayrıca araştırmanın sonucunda, çalışmaya katılan adayların ögrencilerin; "kavram yanılgılarını ve bir performans sergileyebilme becerilerini tespit edebilmelerine", "üst düzey düşünebilme, sistemli çalışabilme, disiplinlerarası 
ilişki kurma, eski ve yeni bilgilerini bütünleştirebilme, yeteneklerini sergileyebilme becerilerinin gelişimine", "arkadaşları tarafından değerlendirilebilmelerine, derse yönelik olumlu tutum geliştirebilmelerine, öğrenilecek konuya yönelik öğrenme motivasyonlarının artmasına" olanak sağlayacak çeşitli ölçme ve değerlendirme araçlarını öğrenme sürecinde etkin olarak kullanabilme yeterlikleri konusunda kararsız oldukları da tespit edilmiştir. Öğretmen adaylarının ölçme ve değerlendirme araçlarını kullanma konusundaki olumsuz ve kararsız oldukları ifadeler incelendiğinde, bu ifadelerin daha çok alternatif ölçme araçlarının kullanımını gerektiren durumları kapsadığı görülmektedir. Araştırmanın nicel verilerinden elde edilen bu sonuçların nedenleri, adaylara yöneltilen açık uçlu sorularla tespit edilmeye çalışılmıştır. Bu doğrultuda araştırmanın nitel verilerinin sonucuna göre, çalışmaya katılan öğretmen adaylarının çeşitli ölçme ve değerlendirme araçlarını; seçebilme konusunda olumlu yeterlik algılarının, özellikle alternatif ölçme araçlarını kullanabilme konusunda ağılıklı olarak olumsuz ve kararsız yeterlik algılarının oluşmasındaki temel faktör, aldıkları ölçme ve değerlendirme dersidir. Adaylar bu dersi kendilerine öğretmenlik meslek bilgisi kazandıran önemli bir ders olarak görmekte, ancak bu dersin teorik ağırlıklı olarak işlenmesini olumsuz yönde eleştirmektedirler. Teorik geçen ders sürecinin ölçme ve değerlendirme araçları konusunda yeterli bilgi birikimlerinin oluşmasına imkân tanıdığını, ancak öğretmenliğin salt teorik bilgi birikimi gerektiren bir meslek olmadığını, hizmet süreçlerinde özellikle alternatif ölçme ve değerlendirme araçlarının kullanımı konusunda -ölçme ve değerlendirme dersinde yeterince uygulama yapılmaması nedeniyle- zorluk yaşayabileceklerini belirtmişlerdir. Hatta adaylardan biri meslek yıllarında, bu zorluğu yaşamamak adına, iyi bildiğinden emin olduğu, kendisinin de öğrenme sürecinde aktif olarak kullanılan geleneksel ölçme ve değerlendirme araçlarını tercih edeceğini açıkça dile getirmiştir. Literatürde bu araştırmadan elde edilen sonuçlara benzer, farklı araştırma sonuçlarına da rastlanmaktadır. Ayan ve Budak (2012) çalışmalarında, sınıf öğretmeni adaylarının bazılarının "ölçme ve değerlendirme yöntem ve tekniklerini belirleme, değişik ölçme tekniklerini kullanarak öğrencilerin öğrenmelerini ölçme" yeterliklerine ilişkin olumsuz görüşlere sahip olduklarını, bu duruma yol açan faktörlerin başında ise ölçme ve değerlendirme ders süreci içinde yapılan uygulama çalışmalarının yetersizliğini gösterdiklerini belirlemişlerdir. Arda (2009) ise çalışmasında, araştırmanın çalışma grubunu oluşturan ilköğretim sınıf öğretmenlerinin bir kısmının alternatif ölçme çalışmaları konusunda yeterli bilgiye sahip olmadıklarını, öğretmenlerin bu durumun nedenini de büyük ölçüde üniversitede verilen teorik bilgiye diğer bir ifade ile pratik eğitimin yetersizliğine bağladıkları sonucuna ulaşmıştır. Erdemir (2007) çalışmasında, araştırmaya katılan öğretmenlerin yarıdan fazlasının mezun oldukları öğretim kurumunda ölçme ve değerlendirme teknikleri ile ilgili uygulamaya dayalı yeterli bilgi almadıklarını, ölçme ve değerlendirme tekniklerini etkin kullanabilme konusunda yeterli olmadıklarını, ölçme araçları içerisinde ağırlıklı olarak geleneksel ölçme araçlarından yazılı ve sözlü sınavlarla çoktan seçmeli testleri kullandıklarını tespit etmiştir. Sonuç olarak bu araştırmanın çalışma grubunu 4. sınıfların oluşturması ve araştırmanın bahar yarıyılında yapıldığı göz önüne alındığında, bu sonuçlardan hareketle çalışmaya katılan öğretmen adaylarından bazılarının ölçme ve değerlendirme alanına ilişkin yeterli donanıma sahip olmadan hizmet süreçlerini tamamlayabilecekleri ihtimali olduğunu söylemek mümkündür.

Akademik çalışmaların çoğunda öğretmen eğitiminde kalitenin önemine değinilmesine rağmen Palardy ve Rumberger (2008), öğretmenlerin hizmet öncesinde aldıkları eğitimin istenilen niteliklerde olmadığını, öğretmen adaylarının mesleklerini hakkıyla yerine getirebilecek donanıma sahip olmadan hizmet öncesi eğitim süreçlerini tamamladıklarını ifade etmektedirler. Bu konuda Kösterelioğlu ve Bayar (2014) öğretmenlerin hizmet öncesi eğitimlerinde çok fazla teorik bilgi edindiklerini ve bu süreçte uygulamaların yetersiz kaldığını belirtmektedirler. Benzer şekilde Beck ve Kosnik (2002), Levine (2011) üniversite tabanlı 
öğretmen eğitimi programlarının aşırı kuramsal olduğu, uygulamayla bağlı olmadığı nedeniyle sürekli eleştirildiklerini belirtmektedirler. Büyük intimalle, teori ve uygulama arasında en çok farkın oluştuğu branş ölçme ve değerlendirmedir, çünkü okullarımızda ölçme ile ilgili bazı etkinlikler yapılmasına rağmen ölçmenin önemi ve faydası yeterince anlaşılmamakta, öğretmenlerimiz hizmet süreçlerinde çok sayıda sınav yapmalarına rağmen ölçme ve değerlendirme ile ilgili çok az ders almaktadırlar (Tan, 2009, s.18). Bu araştırmaya katılan öğretmen adayları da yüksek olasılıkla meslekleri sürecinde birçok ölçme ve değerlendirme araçlarını kullanmaya intiyaç duyacaklardır. Ancak bu araçların teorik bilgisi ile uygulanış şekli arasında bağlantıyı istenilen düzeyde kuramamaları, adayları en iyi bildikleri araçları eğitimöğretim sürecinde kullanma yoluna itebilecek, dolayısıyla öğrenci açısından öğrenme süreci belki de öğretmenin bildiklerinin ötesine geçemeyecektir. Dolayısıyla öğretmen adaylarının çeşitli amaçlarla ölçme ve değerlendirme araçlarını, özellikle de alternatif ölçme ve değerlendirme araçlarını, kullanabilme konusundaki yeterlik algılarının iyileştirilmesi amacıyla, öğrenme sürecinde teori ve uygulamayı bütünleştiren çalışmaların yapılmasına ihtiyaç duyulmaktadır. Nitekim Arslan (2011) çalışmasında, beden eğitimi öğretmen adaylarının ağırlıklı olarak eğitimde ölçme ve değerlendirme ile beden eğitiminde alternatif ölçme ve değerlendirme konularınında teorik ve uygulamalı eğitim almalarını sağlamak amacıyla Ölçme ve Değerlendirme Gelişim Programı (ÖDGP) hazırlamış ve uygulamıştır. Çalışmanın sonucunda araştırmacı, ÖDGP sonrasında öğretmen adaylarının eğitimde ölçme ve değerlendirmeye ilişkin genel yeterlik algılarında ve alternatif ölçme araçlarını kullanabilme yeterlik algılarında anlamlı düzeyde bir artış olduğu sonucuna ulaşmıştır.

Bu araştırmadan elde edilen bir diğer sonuç, araştırmaya katılan öğretmen adaylarının Türkiye'de uygulanan eğitim sistemini, öğrenme sürecinde ağırlıklı olarak geleneksel ölçme ve değerlendirme araçlarının kullanıldı̆̆ı gerekçesiyle eleştirdiklerinin tespitidir. Çalışmaya katılan adaylar ülkemizin hemen tüm eğitim kademelerinde geleneksel ölçme araçlarının yaygın olarak kullanıldığını, dolayısıyla alternatif ölçme ve değerlendirme araçlarının kullanımı konusunda yeterli bilgi ve beceri birikimlerinin oluşmadığını, bu durumun da genel olarak ölçmek istedikleri davranışa uygun özellikle alternatif ölçme ve değerlendirme araçlarını kullanma konusundaki yeterliklerini olumsuz yönde etkilediğini ifade etmişlerdir. Benzer şekilde Sarıca (2016) çalışmasında, araştırmaya katılan öğretmen adaylarının öğrenme süreçlerinde, alternatif ölçme ve değerlendirme araçları ile ilgili yaşantı ve tecrübeleri eksik olduğundan, öğrenme süreçlerinde daha çok klasik değerlendirme ile değerlendirilmeyi tercih ettikleri sonucuna ulaşmıştır. Literatür incelendiğinde öğretmen adaylarının ve öğretmenlerin eğitim sistemimizde yoğun olarak kullanılan ölçme ve değerlendirme araçları oldukları ve dolayısıyla bu araçları iyi bildikleri gerekçesi ile, öğrenme sürecinde ağırlıklı olarak geleneksel ölçme ve değerlendirme araçlarını kullandıklarını veya kullanma isteğinde olduklarını gösteren araştırmalara rastlanmaktadır (Çiftçi, Sünbül, Köksal, 2013; Alaz ve Yarar, 2009; Şimşek, 2011; Sabancı ve Yazıcı, 2017). Burada asıl üzerinde durulması gereken konu "balık baştan kokar" mantığı ile yüksek öğretimde uygulanan ölçme ve değerlendirme sistemidir. Yüksek öğretimde de ilk, orta ve lise öğretim programlarında yer verilen çoklu ölçme ve değerlendirme sistemi benimsenip yaygın olarak kullanılmaya başlanmadığı sürece, bu kademelerde yetişen öğretmenlerimizin geleneksel ve alternatif ölçme ve değerlendirme araçlarının kullanımı konusunda aynı yeterlik algılarına sahip olmalarını ve bu araçları aynı sıklıkta kullanmalarını beklemek, hem iğneyi hem çuvaldızı öğretmenlerimize batırmak demek olacaktır. Bu nedenle bu araştırmanın yürütüldüğü üniversitede dahil olmak üzere öğretmen yetiştiren tüm yüksek öğretim kurumlarında, öğretmen adaylarımızın öğrenim süreçlerinde, alt kademelerden başlayarak alternatif ölçme ve değerlendirme araçlarının kullanımı konusunda deneyim yaşamalarını sağlayacak çalışmaların yapılması gerekli ve önemlidir. 
Bu araştırmanın sonucunda göze çarpan bir diğer bulgu ise, çalışmaya katılan öğretmen adaylarının çeşitli ölçme ve değerlendirme araçlarını seçebilme yeterliklerini etkileyen faktörlerden biri olarak sadece $3(f=3, \% 3)$ adayın "mesleki gelişim sağlamak amacıyla gösterilen bireysel çabalar" olduğunu ifade etmeleridir. Bu araştırmada ölçme ve değerlendirme alanıyla ilgili niteliklerini, mesleki gelişim amacıyla arttırmaya çalışan öğretmen adayının nicelik olarak bu kadar az olması araştırma için beklenmedik bir sonuçtur. Araştırmanın nitel verileri incelendiğinde, adaylar bu duruma yol açan temel faktörün Kamu Personeli Seçme Sınavı (KPSS) olduğunu belirtmişlerdir. Öğretmen adayları son sınıfta KPSS hazırlık aşamasında olduklarını, dolayısıyla mesleki gelişimleri için sınava hazırlanmaktan başka ek bir çalışma yapamadıklarını açıkça dile getirmişlerdir. Erarslan (2006) öğretmen adaylarının görüşlerine göre öğretmenlik mesleğinde girişte KPSS yöntemini incelediği çalışmasında, öğretmen adaylarının öğretmenlik programlarının son sınıflarında KPSS kaygıSı nedeniyle programı takip edemedikleri, hizmet öncesi eğitimlerinin son yılında fakülte eğitimi yerine KPSS'ye hazırlandıkları sonucuna ulaşmışır. Güven (2010) KPSS sonuçlarına göre öğretmen istihdamının, eğitim fakültelerinde verilen eğitimi göz ardı ederek merkezi sistem sınavlarına hazırlayan dershanelere yönelen ve KPSS'de başarıya odaklı bir aday öğretmen profilinin oluşmasına yol açtığını, öğretmenlik mesleğine girişin çok yönlü bir değerlendirme ile olması gerektiğini belirtmiştir. İyi bir öğretmenle ilgili değerlendirmelere bakıldığında iyi bir öğretmenin "kendisini mesleki ve kişisel açılarından sürekli olarak geliştiren, kendisini geliştirmeyle ilgili fırsatları ve olanakları araştıran ve değerlendiren öğretmen" şeklinde bir tanımlama göze çarpmaktadır (Seferoğlu, 2004). Bu araştırmaya katılan öğretmen adaylarının de belirtilen bu iyi öğretmen kriterlerini taşımayabilmeleri için mesleki gelişime önem vermeleri gerekli görülmektedir. Bu doğrultuda çalışmaların başlangıç noktasını Ertem (2013)'in belirttiği gibi “öğretmen adaylarında mesleki gelişim ihtiyacı farkındalığının oluşturulması gerekliliği" oluşturmalıdır.

Son olarak bu çalışmada, araştırmaya katılan temel eğitim bölümü öğretmen adaylarının uygulama amaçlarına göre çeşitli ölçme ve değerlendirme araçlarını seçebilme ve kullanabilme yeterlik algılarının adayların cinsiyet ve anabilim dallarına göre farklılaşmadığı tespit edilmiştir. Bu durum araştırmanın yürütüldüğü üniversitenin temel eğitim bölümünde ölçme ve değerlendirme derslerinin farklı öğretim elemanları tarafından yürütülmüş olmasına rağmen benzer şekilde işlenişinden kaynaklanıyor olabilir. Araştırmadan elde edilen bu bulguya benzer olarak Karaca (2003) çalışmasında, öğretmen adaylarının ölçme aracını uygulama konusundaki yeterlik algılarının adayların cinsiyet ve kayıtlı oldukları anabilim dallarına göre farklılaşmadığını tespit etmiştir. Yavuz (2011) ise çalışmasında öğretmen adaylarının ölçme ve değerlendirme yeterlik alanları olan "ölçme değerlendirme yöntem ve tekniklerini belirleme", "değişik ölçme tekniklerini kullanarak öğrencilerin öğrenmelerini ölçme" yeterliklerine ilişkin görüşlerinde cinsiyet değişkenine göre anlamlı bir farklılaşma meydana gelmediğini ancak anabilim dalı değişkenine göre anlamlı bir fark olduğunu, bu yeterlik alanlarına ilişkin okul öncesi öğretmen adaylarının sınıf öğretmeni adaylarına göre daha düşük yeterlik düzeyine sahip olduklarını tespit etmiştir.

Bu araştırmadan elde edilen sonuçlar ışığında aşağıdaki öneriler geliştirilmiştir:

1. Öğretmenlerimizin yapılandırmacı yaklaşıma dayalı programların ön gördüğg̈ çoklu ölçme ve değerlendirme sistemini başarıyla yürütebilmelerini sağlamak amacıyla, öğretmen yetiştirme lisans öğretim programlarında yer alan ölçme ve değerlendirme derslerinin içeriğindeki uygulamalı etkinliklerinin sayıları arttırılabilinir. Ayrıca bir mikroöğretim çalışması kapsamında ölçme ve değerlendirme dersinde, temel eğitim kademesindeki öğretim programlarında yer alan ölçme ve değerlendirme çalışmaları yürütülerek, 
öğretmen adaylarının bu araçlarının kullanımı konusunda yeterlik düzeylerinin arttırıması sağlanabilinir.

2. Yüksek öğretimde alternatif ölçme ve değerlendirme araçlarının kullanımına ağırlık verilebilinir, uygulamalı örnekler ve çalışmalarla bu araçların nasıl kullanılacağı konusunda öğretmen adayların bilgi ve beceri düzeylerinin artmasına imkân sağlanabilinir, böylelikle öğretmen adaylarına bu araçların kullanımı konusunda deneyim yaşamaları sağlanabilinir.

3. Öğretmen adayları, öğretmenler ve eğitim bilimleri alan uzmanlarının katılımıyla, öğretmen adaylarının mesleki gelişimin önemini daha iyi kavramalarını sağlayacak, adayları mesleki gelişimlerini arttırmaya yöneltecek faktörlerin tespiti üzerine çalıştaylar düzenlenebilir. Öğretmenlik meslek bilgisi dersleri kapsamında; mesleki gelişimin önemi, mesleki nitelikleri arttıracak programlar hakkında bilgiler, öğretmen adaylarının niteliklerini yükseltebilmelerine yardımcı olacak bilgi ve iletişim teknolojilerinin kullanımı (örneğin; http://www.meb.gov.tr, http://ttkb.meb.gov.tr vb.) konularına ağırlık verilebilinir.

4. Öğretmen adaylarının lisans aldıkları ölçme ve değerlendirme dersine yönelik eğitimi yeterli buldukça ölçme ve değerlendirme hakkındaki yeterlik algılarının arttığı (Sabancı ve Yazıcı, 2017) bilgisinden hareketle, üniversitelerde verilen ölçme ve değerlendirme dersinin, öğretmen adaylarının mesleki yıllarında ihtiyaçlarını karşılayacak nitelikte işlenmesinin sağlanması önerilebilinir.

5. Gelecekte öğretmen adaylarının alternatif ölçme ve değerlendirme araçlarının kullanımı konusunda bilgi ve beceri düzeylerini arttırmaya imkân tanıyacak uygulama ağırlıklı gelişim programları hazırlanıp uygulanabilinir. Yapılacak olan deneysel çalışmalarla bu gelişim programlarının öğrenenlerin alternatif ölçme ve değerlendirme tekniklerinin kullanımına ilişkin öğretmen adaylarının yeterlik algılarına olumlu yönde etkisi olup olmadığı incelenebilinir.

\section{KAYNAKLAR}

Alaz, A. ve Yarar, S. (2009). Ölçme-değerlendirme sürecinde sınıf öğretmenlerinin tercihleri ve sebepleri. The First Intenational Congress Educational Research, 1-3 Mayıs, Çanakkale. http://www.eab.org.tr/eab/oc/egtconf/pdfkitap/indexb.php?link=2

Anıl, D. ve Acar, M. (2008). Sınıf öğretmenlerinin ölçme değerlendirme sürecinde karşılaştıkları sorunlara ilişkin görüşleri. Yüzüncü Yıl Üniversitesi Eğitim Fakültesi Dergisi, V(II), 44-61.

Arda, D. (2009). Ilköğretim sınıf öğretmenlerinin 2005 öğretim programı ekseninde ölçme ve değerlendirme alanındaki yeterlilik ve görüşlerinin incelenmesi. (Yayımlanmamış Yüksek Lisans Tezi). Marmara Üniversitesi, İstanbul.

Arslan, Y. (2011). Ölçme ve değerlendirme gelişim programının beden eğitimi öğretmen adayları ve ders verdikleri öğrencilerinin ölçme ve değerlendirmeye ilişkin algı düzeylerine etkisi. (Yayımlanmamış Doktora Tezi), Hacettepe Üniversitesi, Sağlık Bilimleri Enstitüsü, Ankara.

Arslantaş, H. í. (2011). Öğretim elemanlarının öğretim stratejileri-yöntem ve teknikleri, iletişim ve ölçme değerlendirme yeterliklerine yönelik öğrenci görüşleri. Mustafa Kemal Üniversitesi Sosyal Bilimler Enstitüsü Dergisi, 8(15), 487 - 506.

Ayan, M. ve Budak, Y. (2012). Eğitim fakültelerinin sınıf öğretmenliği programlarının öğretmenlik mesleği genel yeterliklerini kazandırma düzeyi. Akdeniz Eğitim Araştırmaları Dergisi, 12, 1-16.

Black, P. ve William, D. (1998). Inside the black box:Raising standards through classroom assessment.http://michiganassessmentconsortium.org/sites/default/files/Inside\%20 
the\%20Black\%20Box\%3A\%20Raising\%20Standards\%20Through\%20Classroom\%20Asses sment.pdf (Erişim tarihi: 2017, 30 Mayıs)

Bayat, S. ve Şentürk, Ş. (2015). Fizik, kimya, biyoloji ortaöğretim alan öğretmenlerinin alternatif ölçme değerlendirme tekniklerine ilişkin görüşleri. Amasya Üniversitesi Eğitim Fakültesi Dergisi, 4(1), 118-135.

Beck, C. ve Kosnik, C. (2002). The importance of the university campus program in preservice teacher education: A Canadian case study. Journal of Teacher Education, 53(5), 420-432.

Benzer, A. ve Eldem, E. (2013). Türkçe ve edebiyat öğretmenlerinin ölçme ve değerlendirme araçları hakkında bilgi düzeyleri. Kastamonu Eğitim Dergisi, 21(2), 649-664.

Büyüköztürk, Ş. (2005). Anket geliştirme. Türk Eğitim Bilimleri Dergisi, 3(2), 297-315.

Büyüköztürk, Ş., Çakmak, E. K., Akgün, Ö. E., Karadeniz, Ş. ve Demirel, F. (2010). Bilimsel araştırma yöntemleri. Ankara: Pegem.

Can, A. (2014). SPSS ile bilimsel araştırma sürecinde nicel veri analizi. Ankara: Pegem.

Cansız-Aktaş, M. ve Baki, A. (2013). Yeni ortaöğretim matematik dersi öğretim programının ölçme değerlendirme boyutu ile ilgili öğretmen görüşleri. Kastamonu Eğitim Dergisi, 21(1), 203-222.

Çiftçi, S., Sünbül, A. M. ve Köksal, O. (2013). Sınıf öğretmenlerinin yapılandırmacı yaklaşıma göre düzenlenmiş mevcut programa ilişkin yaklaşımlarının ve uygulamalarının eğitim müfettişlerinin görüşlerine göre değerlendirilmesi. Mersin Üniversitesi Eğitim Fakültesi Dergisi, 9 (1), 281-295.

Ellwein, M. C. ve Graue, M. E. (1996). Assessment as a way of knowing children. In C. A. Grant ve M. L. Gomez (Eds.), Making schooling multicultural: Campus and classroom. Englewood Cliffs, NJ: Merrill.

Eraslan, L. (2006). Öğretmenlik mesleğine girişte Kamu Personeli Seçme Sınavı (KPSS) yönteminin değerlendirilmesi. Uluslararası Insan Bilimleri Dergisi,1(1), 1-31.

Erdemir, Z. A. (2007). Ilköğretim ikinci kademe öğretmenlerinin ölçme değerlendirme tekniklerini etkin kullanabilme yeterliliklerinin araştırılması (Kahramanmaraş örneği). (Yayımlanmamış Yüksek Lisans Tezi). Kahramanmaraş Sütçü İmam Üniversitesi, Kahramanmaraş.

Ertem, S. í. (2013). Sınıf öğretmeni adaylarının öğretmenlik mesleği özel alan yeterliklerine ilişkin görüşlerinin değerlendirilmesi. Akdeniz Eğitim Araştırmaları Dergisi, 13, 11-18.

Gay, L. R. (2013). Educational evaluation and measurement. London: Charles Merril.

Gelbal, S. ve Kelecioğlu, H. (2007). Öğretmenlerin ölçme ve değerlendirme yöntemleri hakkındaki yeterlik algıları ve karşılaştıkları sorunlar. Hacettepe Üniversitesi Eğitim Fakültesi Dergisi, 33, 135-145.

Güven, D. (2010). Profesyonel bir meslek olarak Türkiye'de öğretmenlik. Boğaziçi Üniversitesi Eğitim Dergisi, 27(2), 13-21

İzci, E., Göktaş, Ö. ve Şad, S. N. (2014). Öğretmen adaylarının alternatif ölçme değerlendirmeye ilişkin görüşleri ve yeterlilik algıları. Ahi Evran Üniversitesi Kırşehir Eğitim Fakültesi Dergisi, 15(2), 37-57.

Karaca, E. (2003). Öğretmen adaylarının ölçme ve değerlendirme yeterliliklerine ilişkin algıları. (Yayımlanmamış Doktora Tezi) Ankara Üniversitesi Eğitim Bilimleri Enstitüsü, Ankara. 
Karasar, N. (2009). Bilimsel araştırma yöntemleri. Ankara: Nobel.

Karamustafaoğlu, S., Çağlak, A. ve Meşeci, B. (2012). Alternatif ölçme değerlendirme araçlarına ilişkin sınıf öğretmenlerinin öz yeterlilikleri. Amasya Üniversitesi Eğitim Fakültesi Dergisi, 1(2), 167-179.

Kesten, A. ve Özdemir, N. (2010). Sosyal bilgiler öğretim programının ölçme değerlendirme boyutunun öğretmen görüşlerine göre değerlendirilmesi: Samsun ili örneği. Fırat Üniversitesi Sosyal Bilimler Dergisi, 20(2), 223-236.

Khattak, H., Mughal, A. W., Marwat, M. K., Jan, S., Waseem, M., ve Bibi, S. (2015). Perception of the students of Sarhad University regarding the impact of different systems of examination upon their academic performance. Asian Journal of Management Sciences \& Education, 4(2), 43-51.

Kösterelioğlu, i. ve Bayar, A. (2014). Türk eğitim sisteminin sorunlarına ilişkin güncel bir değerlendirme. International Journal of Social Science, 25-I, 177-187.

Levine, A. (2011). The new normal of teacher education. The Chronicle Of Higher Education. http://www.chronicle.com/article/The-New-Normal-of-Teacher/127430 (Erişim Tarihi: 2017, 31 Mayıs)

Matsenjwa, L. R. ve Thwala, S. K. (2013). Primary school teachers' knowledge and skills of measurement and assessment: A case of Swaziland. Problems Of Education In The $21^{\text {st }}$ Century, 55, 74-87.

Milli Eğitim Bakanlığı (MEB). (2005). ilköğretim fen ve teknoloji dersi (4 ve 5. Sınıflar) öğretim programı. http://ttkb.meb.gov.tr/www/ogretim-programlari/icerik/72 (Erişim Tarihi: 2017, 22 Mayıs)

Milli Eğitim Bakanlığı (MEB) (2005a). Sosyal bilgiler dersi (4-5. Sınıflar) öğretim programı ve kılavuzu http://ttkb.meb.gov.tr/www/ogretim-programlari/icerik/72 (Erişim Tarihi: 2017, 22 Mayıs)

Munshi, P., Javed, M. ve Hussain, I. (2012). Examination in semester system: What is observation of faculty and students? The Sindh University Journal of Education, 41(2011-12), 76-92.

Palardy, G. J. ve Rumberger, R. W. (2008). Teacher effectiveness in first grade: The importance of background qualifications, attitudes, instructional practices for student learning. Educational Evaluation and Policy Analysis, 30(2), 111-140.

Sabancı, O. ve Yazıcı, K. (2017). Öğretmen adaylarının ölçme ve değerlendirmeye yönelik yeterlik algılarının incelenmesi. Trakya Üniversitesi Eğitim Fakültesi Dergisi, 7(7), 128153.

Sağlam-Arslan, A., Devecioğlu-Kaymakçı, Y. ve Arslan, S. (2009). Alternatif ölçmedeğerlendirme etkinliklerinde karşılaşılan problemler: Fen ve teknoloji öğretmenleri örneği. Ondokuz Mayıs Üniversitesi Eğitim Fakültesi Dergisi, 28, 1-12.

Sarıca, R. (2016). Araştırmaya dayalı öğretim uygulamalarının ölçme ve değerlendirme dersindeki etkisinin incelenmesi. (Yayımlanmamış Doktora Tezi), Gaziantep Üniversitesi Eğitim Bilimleri Enstitüsü, Gaziantep.

Sarıbaş, S. ve Babadağ, G. (2015). Temel eğitimin temel sorunları. Anadolu Eğitim Liderliği ve Öğretim Dergisi, 3 (1), 18-34. 
Seferoğlu, S. S. (2004). Öğretmen yeterlikleri ve mesleki gelişim. Bilim ve Aklın Aydınlığında Eğitim, 58, 40-45.

Shepard, L. A.(2000). The role of classroom assessment in teaching and learning. Center for the Study of Evaluation Technical Report 517. http://cresst.org/wpcontent/uploads/TECH517.pdf (Erişim tarihi: 2017, 18 Mayıs)

Sönmez-Ektem I., Erben-Keçici, S. ve Pilten, G. (2016). Sınıf öğretmenlerinin süreç odaklı ölçme ve değerlendirme yöntemlerine ilişkin görüşleri. Ahi Evran Üniversitesi Kırşehir Eğitim Fakültesi Dergisi 17(3), 661-680.

Şad, S. N. ve Göktaş, Ö. (2013). Öğretim elemanlarının geleneksel ve çağdaş ölçme değerlendirme yaklaşımlarının incelenmesi. Ege Eğitim Dergisi, (14) 2, 79-105.

Şimşek, N. (2011). Sosyal bilgiler dersinde alternatif ölçme değerlendirme araçlarının kullanılması: Nitel bir çalışma. Fırat Üniversitesi Sosyal Bilimler Dergisi, 21(1), 149-168.

Talim Terbiye Kurulu Başkanlığı (TTKB) (2005). B.08.0.TTK.0.01.01/12225 Sayılı, "Ölçme ve Değerlendirme Uygulamaları ile ilgili Açıklamalar" Konulu Genelge. http://www.memurlar.net/haber/35732/olcme-ve-degerlendirme-uygulamalari-ile-ilgiliaciklamalar.html (Erişim Tarihi: 2017, 02 Mayıs)

Tan, Ş. (2009). Eğitimde ölçme ve değerlendirme KPSS el kitabı. Ankara: Pegem.

Tshabalala, T. ve Ncube, A. C. (2014). The effectiveness of measurement and evaluation in Zimbabwean primary schools: Teachers and heads' perceptions. International Journal of Innovation and Applied Studies, 8(1), 141-148.

Uğurlu, R. ve Akkoç, H. (2011). Matematik öğretmen adaylarının ölçme-değerlendirme bilgilerinin gelişiminin tamamlayıcı-şekillendirici ölçme-değerlendirme bağlamında incelenmesi. Pamukkale Üniversitesi Eğitim Fakültesi Dergisi, 30(II), 155-167.

Yavuz, G. (2011). Öğretmen adaylarının öğrenme öğretme süreci ve ölçme değerlendirme alanındaki yeterliklerine ilişkin görüşleri (Yayımlanmamış Yüksek Lisans Tezi), Mersin Üniversitesi Eğitim Bilimleri Enstitüsü, Mersin.

Yeşilyurt, E. (2012). Öğretmen adaylarının ölçme ve değerlendirme alanına ilişkin genel yeterlik algıları. Mustafa Kemal Üniversitesi Sosyal Bilimler Enstitüsü Dergisi. 17(9), 377-395.

Yetkin, D. ve Daşcan, Ö. (2006). Son değişiklikler ile ilköğretim programı 1-5. Sınıflar. Ankara:Anı.

Yıldııım, A. ve Şimşek, H. (2013). Sosyal bilimlerde nitel araştırma yöntemleri. Ankara:Seçkin.

Yılmaz, H. ve Sünbül, A. M. (2007). Öğretimde planlama ve değerlendirme. Konya:Çizgi.

Yücedağ, A. (1993). Anket geliştirilmesi ve uygulanması. Ankara Üniversitesi Eğitim Bilimleri Fakültesi Dergisi, 26(2), 443-454. 


\section{SUMMARY}

The aim of this study was to determine to what extent basic education preservice teachers found themselves competent in selecting and using the assessment tools according to the purpose of the implementation and whether these competency perceptions differed according to gender and department. It was also within the scope of the study to obtain the perspectives of preservice teachers about the factors affecting their competence of selecting and using various assessment tools to better analyze the findings.

The study was a descriptive study designed as a relational survey model. A total of 108 senior preservice teachers from the Department of Basic Education in the Educational Faculty of Kafkas University during the 2015-2016 academic year participated in the study. The data were collected using the Preservice Teachers' Competency Perceptions of Selecting and Using Assessment Tools questionnaire developed by the researcher. The qualitative data were analyzed using frequency (f), percentages (\%), and the chi-square test. Descriptive analysis method was used to analyze the qualitative data. The direct quotations of participants' perspectives were included to ensure the validity of the descriptive analysis. The preservice teachers' responses to the open-ended questions were further coded by an expert to determine the reliability of the analysis, and necessary changes were carried out.

The general result of the study was that the participants found themselves quite competent in selecting various assessment tools according to the purpose of the implementation. However, they did not find themselves equally competent in using these tools. It was found that participants could select various assessment tools in an attempt to identify how students could better learn; the effectiveness of strategy, method, and techniques used in the learning process; the learning difficulties; and the individual characteristics to develop the students' ability to establish a connection between listening, thinking, reading, and writing skills, and enable them to be assessed by their parents. In other words, the participants were determined to have the theoretical knowledge of which assessment tool could be used for these purposes.

However, the present study found that the preservice teachers did not have the sufficient knowledge and skill to use the tools specially selected for the previously mentioned purposes. In addition, participants were uncertain about their competence of using various assessment tools in the learning process that enabled them to identify students' misconceptions and performance skills; develop students' skills of high-level thinking, systematic studying, integrating prior and new knowledge, and performing their abilities; and increase peer assessment, the positive attitudes toward the lesson, and the learning motivation toward the content. Preservice teachers' negative and uncertain statements regarding the use of assessment tools were mostly seen in situations that required the use of alternative assessment tools. The qualitative data revealed that the participants asserted the assessment course that they took as the main reason for their positive competency perceptions of selecting various assessment tools, especially for their mostly negative and uncertain competency perceptions of using alternative assessment tools. Preservice teachers considered this course as a significant course that enabled them to acquire the professional teaching knowledge; however, they criticized the theoretical nature of the course.

The present study also demonstrated that preservice teachers criticized the educational system of Turkey with the proposition that the traditional assessment tools were dominantly used in the learning system. The participants indicated that the traditional assessment tools were prevalently used in almost all educational levels of the country. Therefore, the knowledge and skills about using alternative assessment tools were not developed. This situation negatively influenced the perceptions of competency in using alternative assessment tools that were appropriate for the behavior that the participants intended to assess. Only three of the participants $(n=3,3 \%)$ indicated "individual efforts performed for the professional development" as one of the factors influencing the perceptions of preservice teachers' competency in selecting various assessment tools. It was unexpected that preservice teachers who attempted to increase their qualifications regarding the assessment for professional development were few. The qualitative data revealed that participants indicated the Public Personnel Selection Examination (PPSE) as the major factor leading to this situation. Preservice teachers clearly mentioned that they were mostly studying PPSE in the senior class and thus were unable to further study besides preparing for the examination regarding their professional development. Lastly, the perceptions of basic education preservice teachers' competency in selecting and using various assessment tools according to the purpose of the implementation were found not to differ according to gender and the department. 